\section{A Quantitative Evaluation of Vietnam's Accession to the ASEAN Free Trade Area}

Emiko Fukase
Will Martin

The World Bank

Development Research Group

Trade

November 1999
The static economic benefits

of Vietnam's accession to the ASEAN Free Trade Area (AFTA) are likely to be relatively small.

The gains from increased access to ASEAN markets would be smail, and they would be offset by the costs of trade diversion on the import side. But binding commitments on protection rates under the AFTA plan could provide an important stepping stone to more beneficial broader liberalization. 
Policy Research Working Paper 2220

\section{Summary findings}

Vietnam's accession to the ASEAN Free Trade Area (AFTA) has been an important step in its integration into the world economy. Fukase and Martin use a multiregion, multisector computable general equilibrium model to evaluate how different trade liberalizaticn policies of Vietnam and its main trading partners affect Vietnam's welfare, taking into account the simultaneous impacts on trade, output, and industrial structure.

They conclude that:

- The static economywide effects of the AFTA liberalization to which Vietnam is currently committed are small. On the import side, the exclusion of a series of products from the AFTA commitments appears to limit the scope of trade creation, and the discriminatory nature of AFTA liberalization would divert Vietnam's trade from non-ASEAN members.

- Vietnam's small initial exports to ASEAN make the gains from improved access to partner markets relatively modest. Since Singapore dominates Vietnam's ASEAN exports and initial protection in Singapore is close to zero, there are few gains from preferred status in this market.

- When Vietnam extends its AFTA commitments to all of its trading partners on a most favored nation basis, its welfare increases substantially - partly because of the greater extent of liberalization, partly because the broader liberalization undoes the costly trade diversion created by the initial discriminatory liberalization, and finally because of the more efficient allocation of resources among Vietnam's industries.
- AFTA, APEC, and unilateral liberalizations affect Vietnam's industries in different ways. AFTA appears to be eefit Vietnam's agriculture by improving its access to the ASEAN market.

- Broad unilateral liberalization beyond AFTA is likely to shift labor away from agriculture and certain importcompeting activities toward relatively labor-intensive manufacturing. Reduced costs for intermediate inputs will benefit domestic production. These sectors conform to Vietnam's current comparative advantage, and undertaking broad unilateral liberalization now seems a promising way to facilitate the subsequent development of competitive firms in more capital- and skill-intensive sectors. By contrast, more intense import competition may lead some import substitution industries (now dependent on protection) to contract.

- The higher level of welfare resulting from more comprehensive liberalization implies that the sectoral protection currently given to capital-intensive and strategic industries is imposing substantial implicit taxes on the rest of the economy.

- All the above suggests that AFTA should be treated as an important initial step toward broader liberalization. Binding international commitments in AFTA and, in due course, at the World Trade Organization can provide a credible signal of Vietnam's commitment to open trade policies that will help stimulate the upgrading of existing firms and investment in efficient and dynamic firms.

This paper - a product of Trade, Development Research Group -- was prepared as part of the AFTA Expansion Project in collaboration with the East Asia and Pacific Region. Copies of the paper are available free from the World Bank, 1818 H Street NW, Washington, DC 20433. Please contact Lili Tabada, room MC3-333, telephone 202-473-6896, fax 202-5221159, Internet address Itabada@worldbank.org. Policy Research Working Papers are also posted on the Web at http:// www.worldbank.org/research/workingpapers. The authors may be contacted at efukase@worldbank.org or wmartin1@worldbank.org. November 1999. (61 pages)

The Policy Research Working Paper Series disseminates the findings of work in progress to encowage the exchange of ideas about development issues. An objective of the series is to get the findings out quickly, even if the presentations are less than fully polished. The papers carry the names of the authors and should be cited accordingly. The findings, interpretations, and conclusions expressed in this paper are entirely those of the authors. They do not necessarily represent the vieu of the World Bank, its Executive Directors, or the countries they represent. 
Draft: Comments Welcome

\title{
A Quantitative Evaluation of Vietnam's Accession to the ASEAN Free Trade Area (AFTA): ${ }^{1}$
}

\author{
Emiko Fukase and Will Martin \\ Development Research Group \\ World Bank, \\ Washington, DC
}

\footnotetext{
* This paper was prepared as part of the AFTA Expansion Project in collaboration with the East Asia Region. We are grateful to Kyle Peters, Victoria Kwakwa, Kazi Matin, and Pham Minh Duc for their support of this project; government authorities for the useful information and insights during the mission in August 1998; participants in the trade workshops in Hanoi and Ho Chi Minh City in April 1999 as well as in a World Bank Trade seminar in June 1999 for the very useful discussions; and to the ASEAN Secretariat, UNDP, Centre for International Economics for assistance with data and understanding of the trade regime. The authors are particularly indebted to Pham Xuan Ai, Nguyen Thi Canh, Nguyen Van Chi, Vu Chi Long, Nguyen Truong Son, Vu Quoc Huy, Nguyen Thang, Ha Huy Thanh, Vo Tri Thanh, Vo Thanh Thu, and Ha Huy Tuan, for their useful comments and suggestions.
} 



\section{Summary Findings}

Vietnam's accession to ASEAN Free Trade Area (AFTA) has been an important step in its integration into the world economy. Fukase and Martin use a multiregional, multisector computable general equilibrium (CGE) model to evaluate how different trade liberalization policies by Vietnam and its main trading partners affect Vietnam's welfare, taking into account the simultaneous impacts on trade, output, and industrial structure.

They conclude that:

- The static economywide effects of AFTA liberalization to which Vietnam is currently committed are small. On the import side, the exclusion of a series of products from the AFTA commitments appears to limit the scope of trade creation, and the discriminatory nature of AFTA liberalization would divert Vietnam's trade from nonASEAN members.

- Vietnam's small initial exports to ASEAN make the gains from improved access to partner markets relatively modest. Since Singapore dominates Vietnam's ASEAN exports and initial protection in Singapore is close to zero, there are few gains from preferred status in this market.

- When Vietnam extends its AFTA commitments to all of its trading partners on a most-favored-nation (MFN) basis, its welfare increases substantially-partly because of the greater extent of liberalization, partly because the broader liberalization undoes the costly trade diversion created by the initial discriminatory liberalization, and finally because of the more efficient allocation of resources among Vietnam's industries.

- AFTA, APEC, and unilateral liberalizations affect Vietnam's industries in different ways. AFTA appears to benefit Vietnam's agriculture by giving it better access to ASEAN market.

- Broader unilateral liberalization beyond AFTA is likely to shift labor from agriculture and certain import competing activities toward relatively labor-intensive manufacturing. Reduced costs for intermediate inputs will benefit domestic production. These sectors conform to Vietnam's current comparative advantage and taking this step now seems a promising way to facilitate the subsequent development of competitive firms in more capital and skill intensive sectors. By contrast, more intense import competition may lead some import substitution industries (now dependent on protection) to contract.

- The higher level of welfare resulting from more comprehensive liberalization implies that the sectoral protection currently given to capital-intensive and strategic industries is costing Vietnam's economy as a whole, imposing substantial implicit taxes on the rest of the economy. 
- All of above suggest that AFTA should be treated as the important initial step towards broader liberalization. Binding international commitments in AFTA and, in due course, at the WTO, can provide a credible signal of Vietnam's commitment to open trade policies that will help stimulate upgrading of existing firms and investment in efficient and dynamic firms. 


\section{A Quantitative Evaluation of Vietnam's Accession to the ASEAN Free Trade Area (AFTA)}

\section{$\underline{\text { I. Introduction }}$}

Since its implementation of doi moi (renovation) in 1986, Vietnam achieved substantial progress in macroeconomic managements and opening up unilaterally its trade and investment policies. .Vietnam's recent accession to ASEAN, APEC, and the accession process to WTO offer substantial opportunities to liberalize further its economic system. Whereas the integration into international trading system is clearly beneficial for Vietnam's economic development, the effects of liberalization on certain domestic industries remain a critical issue among Vietnamese policy makers. Information on the consequences of further liberalization is clearly needed as a basis for decisions on deepening the current reforms.

Important insights into the implications of liberalization can be obtained using relatively straightforward analytical tools based on theory and the available data. However, a comprehensive evaluation of the implications for trade, industrial structure and output requires a more sophisticated analytical framework. In this paper, we begin by examining some of the key features of the Vietnamese economy and its trade regime. We then use a multi-region and multi-sector Computable General Equilibrium (CGE) model to evaluate the impacts of alternative policies by both Vietnam and its main trading partners.

Inevitably, the implications of reforms such as AFTA membership and further liberalization will depend upon the structure of Vietnam's economy and the nature of its economic links with its AFTA partners. Section II therefore examines Vietnam's position 
in ASEAN including its size of economy and factor endowments. Direction of trade, composition of trade with ASEAN and non-ASEAN countries, and revealed comparative advantage (RCA) measures for the ASEAN 10 are also examined. Section III reviews Vietnam's current trade regime including its tariff and non-tariff measures. Section IV presents the nature of AFTA and Vietnam's liberalization strategy. Section V. demonstrates the modeling approach and experiments analyzing Vietnam's AFTA commitments and some alternative scenarios. Section VI presents some brief conclusions.

\section{Vietnam's Position in ASEAN}

\section{II.1. Vietnam's Size of Economy, Openness, and Factor Endowments}

Table 1 presents some key economic indicators for the ASEAN countries.

Table 1. Key Economic Indicators of ASEAN 10 countries

\begin{tabular}{|c|c|c|c|c|c|c|c|c|c|}
\hline & GDP 1996 & $\begin{array}{c}\text { Average } \\
\text { Annual } \\
\text { Growth } \\
\text { Rate } \\
1990-96\end{array}$ & $\begin{array}{c}\text { GDP } \\
\text { Per } \\
\text { Capita }\end{array}$ & Population & $\begin{array}{c}\text { Imports } \\
1996\end{array}$ & $\begin{array}{c}\text { Exports } \\
1996\end{array}$ & $\begin{array}{l}\text { Openness } \\
\text { Index }\end{array}$ & $\begin{array}{c}\text { Arable Land } \\
1994-1996\end{array}$ & $\begin{array}{c}\text { Gross } \\
\text { Enrollment } \\
\text { Ratio of } \\
\text { Secondary } \\
\text { Education }\end{array}$ \\
\hline & (\$ mil.) & $(\%)$ & (\$) & (\$ mil.) & (\$ mil.) & (\$ mil.) & (\%) & $\begin{array}{l}\text { (hectares } \\
\text { per capita) }\end{array}$ & $(\%)$ \\
\hline Indonesia & 225828 & 7.7 & 1146 & 197 & 42925 & 49727 & 41 & 0.09 & 48 \\
\hline Cambodia & 3125 & 6.5 & 313 & 10 & 1647 & 300 & 62.3 & 0.39 & 27 \\
\hline Lao PDR & 1857 & 6.7 & 371 & 5 & 642 & 334 & 52.6 & 0.19 & 25 \\
\hline Malaysia & 99213 & 8.7 & 4724 & 21 & 76082 & 78151 & 155.5 & 0.09 & 61 \\
\hline Myanmar & na & 5.7 & na & 46 & 2524 & 1187 & na & 0.21 & 32 \\
\hline Philippines & 83840 & 6.8 & 1164 & 72 & 34663 & 20328 & 65.6 & 0.08 & 79 \\
\hline Singapore & 94063 & 8.7 & 31354 & 3 & 131083 & 124794 & 272 & 0.00 & 84 \\
\hline Thailand & 185048 & 8.3 & 3084 & 60 & 73289 & 55789 & 69.8 & 0.29 & 55 \\
\hline Vietnam & 23340 & 8.5 & 311 & 75 & 13910 & 7016 & 89.7 & 0.08 & 47 \\
\hline Total & 716309 & & & 489 & 376765 & 337626 & & & \\
\hline
\end{tabular}

Source: World Bank, World Development Indicators 1998a 
ASEAN is a diverse group with a combined GDP of $\$ 716$ billion and 489 million people. ${ }^{1}$ With its 75 million people, Vietnam is the second most populous member country after Indonesia. However, given its low-income level per capita, its shares of GDP and trade in ASEAN remain relatively small, accounting for 3.3 percent and 2.9 percent respectively.

Vietnam was one of the fastest growing economies during the period 1990 to 1996, registering an annual average growth rate of 8.5 percent. In 1996, imports plus exports relative to GDP had reached 89.7 percent of GDP, a relatively high figure for a populous country. Although Vietnam's economy is predominantly agricultural, Vietnam's arable land per capita is relatively low accounting for 0.08 hectares per capita. Vietnam is accumulating human capital relatively quickly through its secondary school enrollment rate of 47 percent.

\section{II.2. Direction of Trade}

Figure 1 and figure 2 present Vietnam's imports by source and exports by destination (General Statistical Office, 1997).

Figure 1 shows that 27 percent of Vietnam's imports were sourced from ASEAN in 1996. Singapore was the leading supplier, accounting for 19 percent of Vietnam's total imports followed by Thailand, Malaysia, Indonesia, the Philippines, the Lao PDR and Cambodia. Figure 1 also highlights the importance of the other APEC countries as

\footnotetext{
'Its member countries belong to different stages of development. Singapore belonged to the 'high income' group with GDP per capita of $\$ 31,354$ in 1996. Malaysia was classified in the 'upper middle income' group with per capita income of $\$ 4,724$ whereas Thailand, the Philippines, Indonesia belonged to the 'lower middle income' with per capita incomes of $\$ 3,084, \$, 1,164$ and $\$ 1,146$ respectively. Along with the other new member countries, Cambodia, Myanmar, the Lao PDR, Vietnam was classified as a 'low income' country with per capita income of \$311 (World Bank, 1998a).
} 
Figure 1. The Sources of Vietnam's Imports in 1996

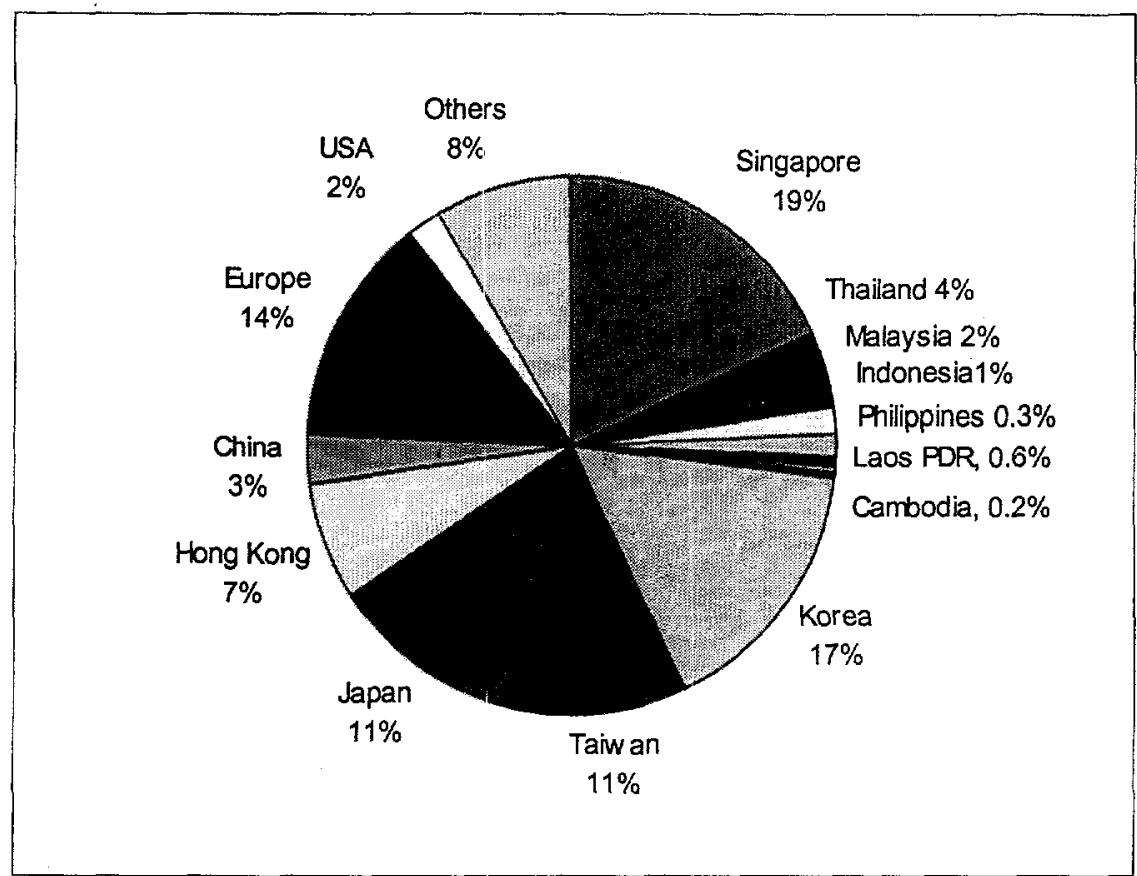

Source: General Statistical Office, Statistical Yearbook 1997

sources of Vietnam's imports. In particular, imports from the other Asian countries, Korea (17 percent), Taiwan (11 percent), and Japan (11 percent) were significant, whereas imports from the United States were rejatively small at 2 percent. APEC countries altogether represent 80 percent of Vietnam's imports (GTAP 4 database). ${ }^{2}$ Besides APEC countries, 14 percent of Vietnam's imports were sourced from the European Union.

\footnotetext{
${ }^{2}$ The members of APEC are Australia; Brunei Darussalam; Canada; Chile; China; Hong Kong, China; Indonesia; Japan, Republic of Korea; Malaysia; Mexico; New Zealand; Papua New Guinea; Republic of the Philippines; Singapore; Taiwan, China; Thailand; and the United States of America. Peru, Russia and Vietnam joined in November 1998.
} 
Figure 2. The Destination of Vietnam's Exports in 1996

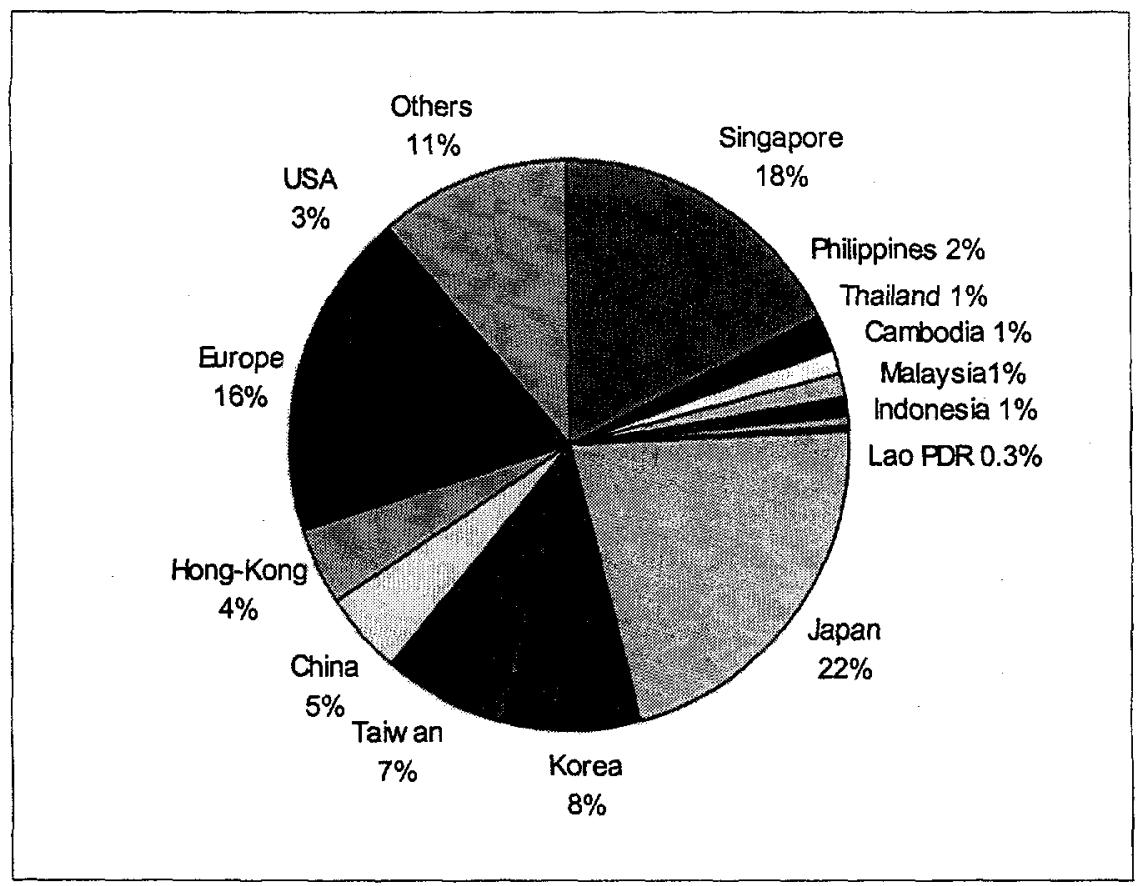

Source: General Statistical Office, Statistical Yearbook 1997

Figure 2 implies that 24 percent of Vietnam's exports were shipped to ASEAN countries. Singapore took 18 percent of Vietnam's exports followed by the Philippines, Thailand, Cambodia, Malaysia, Indonesia, and the Lao PDR. Yietnam's exports to the APEC countries are important accounting for 74 percent of Vietnam's exports. Japan alone received 22 percent of Vietnam's exports in 1996. Besides the APEC countries, the European countries were important destinations representing 16 percent of Vietnam's exports.

Table 2 presents Vietnam's imports and exports with ASEAN member countries for the years 1994-1996. Vietnam's imports from and exports to ASEAN increased by 77 percent and 99 percent respectively, primarily through increased trade with Singapore. During the same period the share of ASEAN remained relatively steady because of rapid growth in trade with other countries. 
Table 2. Vietnam's Imports and Exports from and to ASEAN 1994-1996.

\begin{tabular}{|c|c|c|c|c|c|c|}
\hline & \multicolumn{3}{|c|}{ IMPORTS } & \multicolumn{3}{|c|}{ EXPORTS } \\
\hline & $\underline{1994}$ & $\underline{1995}$ & $\underline{1996}$ & 1994 & 1995 & 1996 \\
\hline Cambodia & 18 & 24 & 18 & 77 & 95 & 99 \\
\hline Indonesia & 116 & 190 & 149 & 35 & 54 & 46 \\
\hline Lao PDR & 103 & 84 & 68 & 21 & 21 & 25 \\
\hline Malaysia & 66 & 191 & 200 & 65 & 111 & 78 \\
\hline Philippines & 15 & 25 & 29 & 4 & 42 & 132 \\
\hline Singapore & 1146 & 1425 & 2033 & 594 & 690 & 1290 \\
\hline Thailand & 226 & 440 & 495 & 98 & 101 & 107 \\
\hline Total ASEAN Trade & 1690 & 2378 & 2991 & 893 & 1112 & 1777 \\
\hline Total Trade & 5826 & 8155 & 11144 & 4054 & 5449 & 7256 \\
\hline ASEAN Share (\%) & 29.0 & 29.2 & 26.8 & 22.0 & 20.4 & 24.4 \\
\hline
\end{tabular}

In millions of U.S.dollars.

Source: General Statistical Office, Statistical Yearbook 1997

\section{II.3. The Composition of Trade: ASEAN vs. Non-ASEAN}

Figure 3 and Figure 4 show the composition of Vietnam's imports and exports from and to ASEAN and non-ASEAN countries. ${ }^{3}$

Figure 3 suggests that Vietnam's leading imports consist of electronics and machinery equipment (MCE) followed by chemical and rubber products (CRP), and basic manufacturing (BMF). A large percentage of Vietnam's imports in these categories are likely to be intermediate inputs and capital goods. The leading imports from ASEAN are

\footnotetext{
${ }^{3}$ The model database was aggregated from the original 50 sectors to thirteen sectors designed to provide a reasonable representation of Vietnam's trade patterns: agriculture and forestry (AGR), basic manufacturing (BMF), beverages and tobacco products (BTP), clothing (CLO), chemical, rubber, plastic products (CRP), coal, oil, gas (COG), light manufacturing (LMF), electronics and machinery (MCE), processed agricultural commodities (PAG), petroleum and coal products (PCP), textiles (TEX), transport equipment (TRP), and others (OTH). Likewise, we combine the 45 Global Trade Analysis Project (GTAP) regions into 12 aggregates: Indonesia (IDN), Malaysia (MYS), the Philippines (PHL), Singapore (SGP), Thailand (THA), Vietnam (VNM), Japan (JPN), the United State (USA), EU15 (EU15), Asian Newly Industrialized countries excluding Singapore (NIES), China (CHN), and the rest of the world (ROW). Annex 4 presents the description of the aggregation.
} 
chemical and rubber products (CRP), mainly fertilizer, resins \& plastic materials from Singapore and Indonesia. Singapore supplies about 78 percent of Vietnam refined petroleum imports (PCP).

Figure 3. Vietnam's Imports ASEAN vs. Non-ASEAN

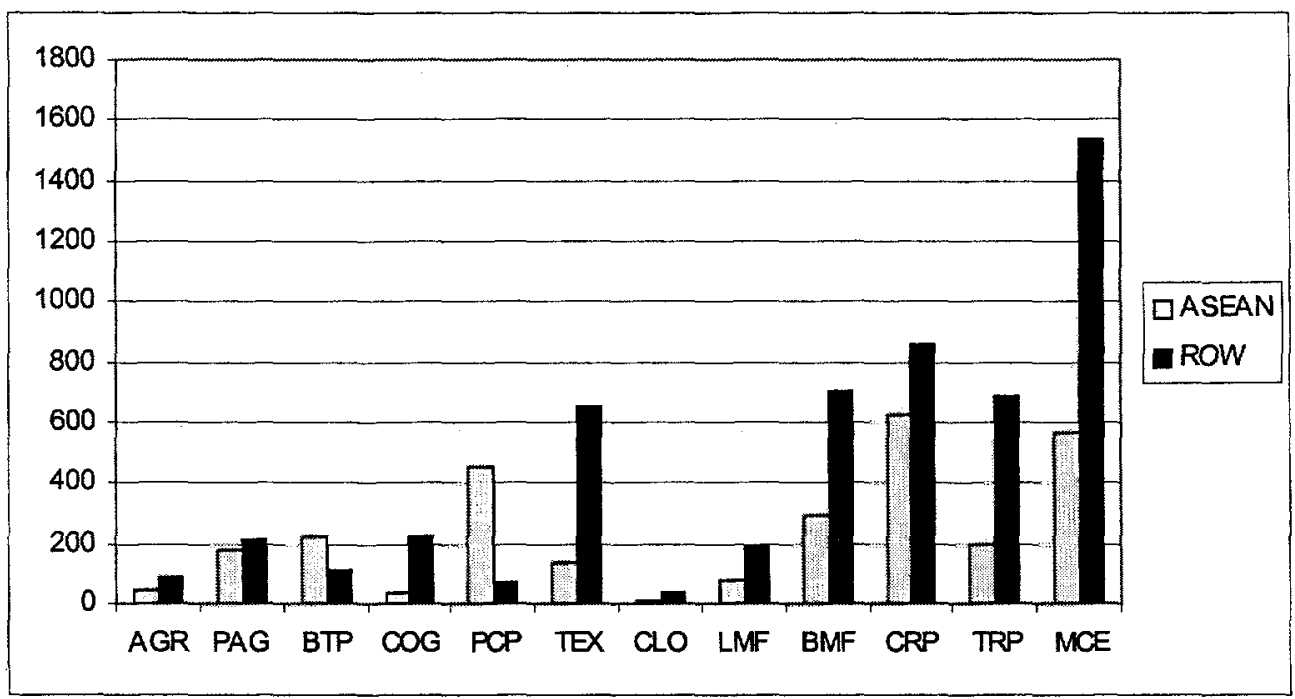

Figure 4. Vietnam's Exports ASEAN vs. non-ASEAN

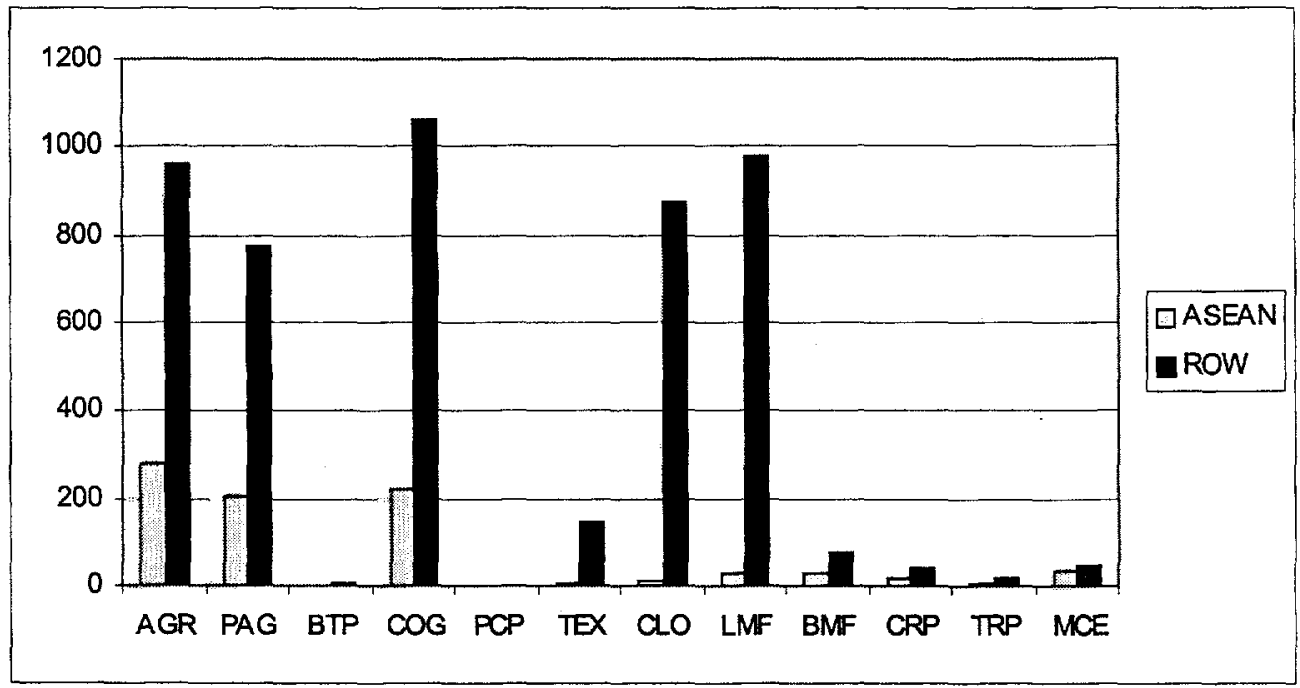

Source: GTAP4 Database 
Figure 4 demonstrates a sharp difference in the composition of exports between ASEAN and non-ASEAN countries. Three categories alone, agriculture and forestry (AGR), processed agricultural commodities (PAG) and coal, oil and gas (COL), dominate Vietnam's exports to ASEAN whereas exports of these commodities are also significant for non-ASEAN destinations. In contrast, textiles (TEX), Clothing (CLO), and light manufacturing (LMF) are shipped mainly to non-ASEAN countries.

\section{Revealed Comparative Advantage (RCA) for the ASEAN 10}

The Revealed Comparative Advantage (RCA) can be a useful indicator of the comparative advantage of countries (Balassa, 1965). Annex 1 presents RCAs for the 10 ASEAN countries. Following Balassa, 'Revealed' Comparative Advantage is defined as the share of a product group in one country's exports divided by that product group's share in world trade.

$R C A_{i j}=\left(x_{i j} / x_{w j}\right) /\left(\sum x_{i j} / \sum x_{w j}\right)$,

where $x_{i j}$ is country $i$ 's export of commodity $j$;

$x_{w j}$ is world's exports of commodity $j$;

$\sum x_{i j}$ is country $i$ 's total exports;

$\sum x_{w j}$ is the world's total exports

With its 'normalization' to remove the effects of price fluctuations and the importance of particular commodities in world markets, the index is preferable to the simple share of a group of products in a country's total exports. It allows clearer comparisons between countries at any time, and allows changes in comparative advantage to be tracked over time. The measure reflects the underlying comparative advantage of the country in particular commodities as determined by technology and factor endowments, modified by 
government policies designed to draw resources into favored sectors. A value of greater than 1 is broadly suggestive of a revealed comparative advantage in sector $i$. The RCA indexes of ASEAN 10 exports are computed at the SITC 2-digit levels and only some of the important items are reported at the 3-digit level.

The index reveals that Vietnam's current comparative advantage lies in primary commodities such as fish, cereals, hides, oilseeds, wood, rubber, coal, and crude oil. Its export shares of rice (SITC 42) and coffee (SITC 71) are approximately 69.7 times and 17 times larger than the world average respectively. Vietnam is also strong in some laborintensive manufactured goods including travel goods, clothing and footwear.

Vietnam's export structure appears to be more or less complementary with higherincome ASEAN members such as Singapore and Malaysia. However, with lower income ASEAN members, Vietnam may compete for certain commodities. For instance, Thailand and Myanmar are also leading exporters of rice with RCAs of 28.7 and 27.6 respectively. Clothing (SITC 84) and footwear are also important for ASEAN in general, especially for the new member countries.

\section{Vietnam's Trade Regime}

Although Vietnam liberalized substantially its trade and investment regime since the latter half of the 1980s, Vietnam's trade regime reflects the legacy of its history as a state dominated centrally planned economy. The state sector still enjoys various forms of privileges including access to land, capital, bail-out facilities, and quota allocations. Import substitution linked to state control and protection remains influential economic ideas (McCarty, 1999). Export industries are promoted by providing subsidies to 
countervail the high relative costs of intermediary products. Because of the importance of this issue in the Vietnamese context, we consider it in some detail.

\section{III.1. Vietnam's Industrialization/Modernization Policy}

With the objective of turning Vietnam into an industrial country by 2020 , Vietnam's industrialization/modernization policy appears to be emphasizing the creation of a diversified industrial structure. To reach that target, much of attention has been paid to develop the industrial base through a combination of export orientation and import substitution. As a part of this clirection, Vietnam appears to be targeting on a set of capital-intensive and so-called strategic industries and to be using trade and investment policies as instruments to promote these industries.

So-called promotion of strategic industries or industry targeting strategies have been advocated by a group of economists for the 'late-industrializing' countries such as Japan; Korea; and Taiwan, China, (Amsden (1989); Wade (1990)). The considerations that are argued to provide grounds for selective state intervention include economies of scale, externalities, and strategic shift of comparative advantage. Wade, for example, argues that liberal trade policies and reallocation according to static comparative advantage only offer once-for all benefit, but do not specify a causal mechanism linking realization of comparative advantage to higher growth. Wade argues that, unlike unalterable natural endowments, government assistance can create new 'acquired' advantages, some of which are industry-specific. The short run allocative costs of establishing internationally competitive industries may be outweighed by the longer run benefits of productivity change in the promoted sectors (Wade, 1990). 
In contrast, several neo-classical economists warn of the dangers of protectionism that may be induced by the rhetoric of 'competitiveness.' For instance, Corden argues that, while there will always be sectoral competitiveness problems, they will not represent a national loss of competitiveness. As is shown by the theory of comparative advantage, all countries will have a comparative advantage in something. Policies of protection will necessarily reduce both imports and exports below free trade levels, reducing the competitiveness of export industries through both direct impacts on the cost of production and real exchange rate appreciation that further increases the costs of exporters. Corden, for example, stresses that sectoral protection only benefits one industry at the expense of others, with a net national loss through forgoing the gains from trade (Corden, 1994). The policy implication is to resist the usual pressures for sectoral protection, and to favor policies that raise national productivity (such as improvements in education and training and the introduction of new technology), which would moderate adverse sectoral effects.

The provision of protection to favored industries can be expected to increase output levels in these industries, by diverting scarce skilled workers from other industries. If the gains from "learning by doing" in these industries were high enough, then an import substitution policy might increase growth rates even while foregoing some of the gains from comparative advantage. The problem may lie with the choice of industries, but this appears to be a problem difficult to avoid. The available studies of openness and growth suggest that protection policies, as actually applied, have substantially reduced economic growth rates in most countries (see, for example, Sachs and Warner 1995; Dollar 1992).

The research results on openness and growth suggest the use of an approach to development in which relatively open economic policies are used to stimulate expansion 
of the industries in which Vietnam currently has a comparative advantage. The relatively higher rates of growth associated with economic growth would then allow the accumulation of capital and the development of the skills needed for modern industrial development. The experience of the high performing East Asian countries has been clear on this point. All of these countries have had very high savings rates and have rapidly upgraded their educational systems to increase their endowments of skilled labor (World Bank 1993). The increases in the stocks of these factors have been important forces leading to the (relative) decline of the traditional agricultural sector and the process of industrialization (Martin and Warr 1.992; Gehlhar, Hertel and Martin 1994).

Rapid economic development involves many changes both in the structure of the economy, and in economic policies. There are many areas in which policy intervention will be required if economic agents are to have the right incentives. The needed interventions will involve establishing a legal framework, and policies that rectify market failures, such as those affecting investment in human capital, or those involving externalities and public goods. As Johnson (1955) has pointed out, tariff protection is a very poor instrument for dealing with any of the problems, such as stimulating infant industries or dealing with externalities, that are usually used to justify it. Policies that directly address the problems, such as the provision of needed public goods or assistance for education and training, are likely to be much better than trade barriers. Given the enormous challenges of development policy, particularly as highlighted by the East Asian financial crisis, there seems to be a strong case for governments to focus on the best available policies for dealing with the challenges before them.

\section{III.2. Foreign Direct Investment (FDI)}


Since Vietnam is capital scare and needs to upgrade its technology, foreign direct investment (FDI) has the potentially very important role in promoting Vietnam's economic development. Since the promulgation of Foreign Investment Law in 1988, FDI commitments to Vietnam totaled almost US\$27 billion with a legal capital of $\$ 11$ billion from 1988 to 1997 (McCarthy, 1998) although FDI commitments fell sharply in $1998 .{ }^{4}$

Puga and Venables (1998) demonstrate that either trade liberalization or import substitution policies may be used by low wage economies to attract industry, but these two policies work through very different mechanisms. If import barriers are raised, industries that seek higher economic profits are attracted, and this in turn leads to import substituting industrialization. Unilateral trade liberalization can also be successful in attracting industry because the availability of low cost intermediate goods and the real exchange rate depreciation ${ }^{5}$ allow foreign firms to source from the most efficient suppliers. Although they both may be superficially 'successful' in attracting industry, they generate different welfare outcomes. While the attraction of investment to exportoriented industries undoubtedly makes the country better off, increased investment in import-substituting industries may actually reduce welfare.

Recent studies by CIE (1998, July) and McCarty (1998) reveal that foreign investment in Vietnam is being directed toward sectors with relatively high levels of

\footnotetext{
${ }^{4} \mathrm{New}$ commitments fell from $\$ 8.5$ billion in 1996 to $\$ 4.0$ billion in 1997 and $\$ 1.8$ billion in 1998 (World Bank, 1998b).

${ }^{5}$ Trade liberalization reduces the prices of the nontraded goods purchased by exporters as well as their prices of intermediate inputs.
} 
protection. ${ }^{6}$ It has been observed that the emphasis of policy seems to be on building up joint ventures between state firms and foreign investors so that physical capital levels of output grow rapidly, rather than encouraging the growth of competitive firms. Most joint ventures were with state enterprises rather than with the domestic private sector. Dollar (1998) warns that powerful alliances among line ministries, large state enterprises, and foreign investors, can create an environment that hampers the development of domestic private enterprises. Protection of powerful up-stream industries, whom the government is often persuaded to protect, is particularly problematic since this would impede the growth of downstream manufacturers ${ }^{7}$ (Flatters, 1998ab).

\section{III.3. Nominal and Effective Rates of Protection}

Table 3 shows a summary of Vietnam's tariff protection.

\footnotetext{
${ }^{6}$ For instance, McCarty (1998) observes that among the five highest sector recipients of FDI (in the tradedgoods sector), cement, fuels, vehicles, electrical machinery, and beverages, all the sectors except fuels are producing import-substituting goods.

${ }^{7}$ An example of plastic product (downstream) and petrochemical (upstream) industries is relevant here. Historically, petrochemical industries were initiated and developed with the government intervention in many Asian countries including Japan, Taiwan, Korea followed by some ASEAN countries. However, Flatters (1998a) points out the danger of similar policies for Vietnam. The plastic products sector has been one of the most successful industries in Vietnam growing at an average rate of almost 30 percent since 1990. Plastics are basic input into a wide range of final consumer goods as well as an essential component in various industrial products (e.g. electronics, electrical appliances and vehicle parts). A crucial factor in the success of the plastic products industry in Vietnam has been the free availability of competitively priced raw materials. Imports of plastic raw materials (PVC resin, polyethylene (PE), polypropylene (PP), polystyrene (PS)) are free of import duties and other non-tariff barriers. Recently, the joint venture project between Japan's Mitsui Corporation and the state-owned Viet Nam National Plastics Corporation (Vinaplast) to manufacture PVC had petitioned to impose 25-40 percent import duty on all PVC resin imports. The government agreed to grant an import tariff of 3 percent and a further import surcharge of 5 percent (Flatters, 1998b). The case of plastic industries illustrates the protection of upstream industry hurts rather than helps the downstream users of these products.
} 
Table 3. The Structure of Vietnam's Protection

\begin{tabular}{|c|c|c|c|c|c|}
\hline \multirow[b]{2}{*}{ GTAP } & \multirow[b]{2}{*}{ Description } & \multicolumn{2}{|c|}{$\begin{array}{c}\text { Nominal Protection of } \\
\text { Import Tariff }\end{array}$} & \multicolumn{2}{|c|}{$\begin{array}{l}\text { Effective Rate of Protection } \\
\text { (ERP) }\end{array}$} \\
\hline & & $\begin{array}{c}\text { Simple } \\
\text { Average } \\
(\%)\end{array}$ & $\begin{array}{c}\frac{\text { Weighted }}{\text { Average }} \\
(\%)\end{array}$ & $\begin{array}{c}\frac{\text { ERP for }}{\frac{\text { Import }}{\text { Substitution }}} \\
(\%)\end{array}$ & $\begin{array}{l}\frac{\text { ERP for }}{\text { Export }} \\
\frac{\text { Production }}{(\%)}\end{array}$ \\
\hline 1 & Paddy rice & 5.0 & 5.0 & 4.2 & -3.8 \\
\hline 2 & Wheat & 3.0 & 3.0 & 3.0 & 0.0 \\
\hline 3 & Cereal grains & 5.9 & 2.6 & -4.6 & -10.0 \\
\hline 4 & Vegetables, fruits, nuts & 24.3 & 27.2 & 41.6 & -8.1 \\
\hline 5 & Oil seeds & 8.6 & 6.5 & 4.4 & -7.1 \\
\hline 6 & Sugar cane, sugar beet & 10.0 & 10.0 & 9.7 & -3.8 \\
\hline 7 & Plant-based fibers & 3.9 & 4.2 & 1.3 & -6.0 \\
\hline 8 & Crops n.e.c. & 13.2 & 6.2 & 4.5 & -5.8 \\
\hline 9 & Bovine cattle, sheep, goats, horses & 4.5 & 4.8 & 0.9 & -7.1 \\
\hline 10 & Animal products n.e.c. & 5.0 & 3.7 & -1.5 & -7.4 \\
\hline 12 & Wool, silk-worm cocoons & 3.0 & 1.3 & -2.2 & -4.2 \\
\hline 13 & Forestry & 4.0 & 1.2 & -20.5 & -22.9 \\
\hline 14 & Fishing & 16.9 & 18.9 & 66.6 & -45.7 \\
\hline 15 & Coal & 3.8 & 3.4 & -14.4 & -22.2 \\
\hline 16 & Oil & 4.5 & 1.0 & -13.9 & -15.9 \\
\hline 17 & Gas & 14.1 & 15.5 & 24.5 & -13.3 \\
\hline 18 & Minerals n.e.c. & 2.3 & 1.1 & -21.4 & -27.0 \\
\hline 19 & Bovine cattle, sheep,goat meat & 12.2 & 10.3 & 12.2 & -3.5 \\
\hline 20 & Meat products n.e.c. & 18.1 & 27.3 & 43.3 & -5.4 \\
\hline 21 & Vegetable oils and fats & 13.1 & 12.3 & 1.4 & -98.5 \\
\hline 22 & Dairy products & 16.7 & 14.5 & 16.3 & -5.7 \\
\hline 23 & Processed rice & 7.5 & 7.5 & 8.0 & -22.5 \\
\hline 24 & Sugar & 30.0 & 30.0 & $\mathrm{Na}^{\mathrm{a}}$ & $n a^{a}$ \\
\hline 25 & Food products n.e.c. & 28.6 & 20.1 & 59.6 & -48.3 \\
\hline 26 & Beverage and tobacco products & 52.1 & 50.2 & $\mathrm{Na}^{\mathrm{a}}$ & $\mathrm{na}^{\mathrm{a}}$ \\
\hline 27 & Textiles & 29.4 & 30.0 & 115.0 & -138.0 \\
\hline 28 & Wearing apparel & 49.2 & 49.4 & 229.8 & -231.9 \\
\hline 29 & Leather products & 18.8 & 13.5 & -15.1 & -67.1 \\
\hline 30 & Wood products & 18.7 & 11.9 & 15.2 & -19.3 \\
\hline 31 & Paper products, publishing & 20.0 & 19.4 & 88.1 & -88.5 \\
\hline 32 & Petroleum, coal products & 9.6 & 44.0 & $\mathrm{Na}^{\mathrm{a}}$ & $n a^{a}$ \\
\hline 33 & Chemical, rubber, plastic, products & 8.8 & 6.4 & -0.1 & -40.3 \\
\hline 34 & Mineral products n.e.c. & 20.7 & 23.8 & 69.6 & -52.3 \\
\hline 35 & Ferrous metals & 5.3 & 6.0 & 3.7 & -25.3 \\
\hline 36 & Metals n.e.c. & 5.8 & 10.4 & 21.9 & -103.8 \\
\hline 37 & Metal products & 18.5 & 16.6 & 34.5 & -33.9 \\
\hline 38 & Motor vehicles and parts & 22.6 & 18.6 & 186.4 & -200.7 \\
\hline 39 & Transport equipment n.e.c. & 13.2 & 28.3 & 56.6 & -32.9 \\
\hline 40 & Electronic equipment & 9.7 & 10.7 & 13.8 & -18.4 \\
\hline 41 & Machinery and equipment n.e.c. & 7.4 & 8.1 & -0.6 & -29.3 \\
\hline 42 & Manufactures n.e.c. & 24.7 & 22.7 & 64.3 & -45.1 \\
\hline & Total & 15.6 & 19.0 & & \\
\hline
\end{tabular}

${ }^{a}$ ERP has not been defined since value added at world prices was negative.

Sources: Centre for International Economics, Vietnam's Tariff Schedule (February 1998); Fukase and Martin (1998) ; GTAP4 database

The first two columns show the nominal rate of protection (NRP) whereas the second two show the effective rate of protection (ERP). Vietnam's current nominal rate of protection indicates 15.6 percent of simple average and 19.0 percent of trade weighted 
averages. There is a general tendency for Vietnam's tariff structure to be relatively low in capital goods and raw materials and higher for finished goods. This pattern of protection increases the returns to value adding factors in the final goods industries. Even quite moderate tariffs on final goods can lead to sharp increases in the returns to value added in a particular sector if intermediate irputs are a large share of total costs. Imports of most basic industrial raw materials are relatively free of import restrictions since Vietnam does not yet have significant upstream steel or plastics industries (Flatters, 1998a). For many goods which are not produced in Vietnam, the tariff rates are virtually zero. This confers a great advantage on domestic users of these products. An indication of the total impact of protection can be obtained using the Effective Rate of Protection (ERP).

The ERP differs from the NRP by taking into account the trade barriers that are imposed on the intermediate inputs used in the production of goods. ${ }^{8}$ Protection granted

\footnotetext{
${ }^{8}$ The effective rate of protection (ERP) is defined as the percentage change in producers' value-added, as a result of taxes on trade, over the level of value-added that would have prevailed in the absence of those taxes. For import substituting industries, the formula for calculating the ERP is

$E R P_{m}=\left(V A_{m j}-V A_{j}^{*}\right) / V A_{j}^{*}$

where $V A_{m j}$ is industry j's value added at domestic prices and $V A_{j}{ }^{*}$ is value added at world prices. $V A_{m j}$ and $V A_{j}{ }^{*}$ are computed as

$V A_{m j}=V O_{j}-\sum I N T_{i j}$

$V A_{j}^{*}=V O_{j} /\left(1+t_{j}\right)-\sum I N T_{i j} /\left(1+t_{i}\right)$
}

where $V O_{j}$ is the value of output of industry $j, I N T_{i j}$ is the use of intermediate input $i$ by industry $j$, and $t_{j}$ is the nominal tariff rate imposed on industry $j$. The ERP for export production can be

$E R P_{x}=\left(V A_{x j}-V A_{j}^{*}\right) / V A_{j}^{*}$

where

$V A_{x j}=V O_{j} /\left(1+t_{j}\right)-\Sigma I N T_{i j}$

$V A_{j}^{*}=V O_{j} /\left(1+t_{j}\right)-\sum I N T_{i j} /\left(1+t_{j}\right)$

Value added at domestic prices for export production $\left(V A_{j} j\right)$ differs from that for import substitution $\left(V A_{m j}\right)$ since exporters face world prices for their sales. 
to final goods increases returns to value adding factors in a sector. By contrast, taxes on intermediate inputs reduce the returns to value adding factors. Protection has different implications for import substituting and export oriented activities. Higher protection on outputs raises the domestic prices for import competing goods and increases the returns involved in producing them. Exporting activities have to face world prices for their sales and so do not benefit from protection on their output. They can only be harmed by protection. The ERP measures provided in this paper capture the direct adverse impacts of protection on these firms. There is an additional adverse impact that arises from the increases in the prices of nontraded goods-the real exchange rate appreciation effect of protection.

The ERPs for Vietnamese industries have been calculated using the input-output table information from the GTAP Version 4 database. The table reveals very high effective rates of assistance for import substitution in industries such as wearing apparel, motor vehicles and parts, and textiles.

The fourth column of Table 3 shows the effective rate of protection applying to a firm that produces for the export market, but is unable to benefit from exemptions of import duties on imported inputs. As expected, the effect of the tariff regime on such a firm is negative, because of the cost-increasing effects of higher prices for intermediate goods.

It is worth noting that the negative effects for exporters are the largest for such industries as apparel and motor vehicles implying increased costs of intermediate goods. This is because the government tends to use tariff and other protective measures on 
intermediate goods to achieve the localization objectives (see Box 1 ). ${ }^{9}$ The resulting increases in the costs of other firms ${ }^{10}$ tends to lead other import competing industries to lobby for even higher levels of nominal rate of protection, and diminishes the competitiveness of export industries.

Two cautions should be born in mind to interpret these protection figures. First, these figures do not include the protective effects of Non Tariff Barriers (NTB). A set of important industries, including cernent, steel, sugar and paper industries, is protected by quantitative restrictions rather than tariff.

Second, the ERP for export production does not include the firms who benefit from duty-draw back system. In fact, Vietnam has applied a number of measures such as duty drawback system and export-processing zones to compensate exporters for some of the costs which Vietnam's own import barriers impose upon them. However, these measures never offset fully the negative effects of protection (Flatters, 1998b; CIE, 1998; Herrou-Aragon, $1999^{11}$ ). In addition, they may hinder the development of

\section{Box 1. Car Industry Policy in Vietnam: On the Road to Nowhere?}

A modern car industry embodies relatively high technology both in its processes and its products and provides great scope for the development of backward linkages to component manufactures. For this reason, many countries have attempted to persuade international auto

\footnotetext{
${ }^{9}$ Regarding to production and assembly of electronics appliance, the localization ratio is at least 20 percent for the first 2 years and must be increased annually; regarding to production and assembly of automobile, the required localization ratio is 5 percent after the first 5 years and must be increased to reach 30 percent after the first 10 years; for motorcycle and spare parts, the required localization ratio is $5-10$ percent after the first 2 years and must be increased to 60 percent after the first 5 years (WTO, 1998).

${ }^{10}$ Both as a direct consequence of higher prices of traded goods, and higher prices of nontraded goods (the real exchange rate appreciation effect of higher protection).

${ }^{11}$ Herrou-Aragon (1999) investigates the case of the Dominican Republic where an escalating import tariff rate structure aimed at protecting import-substitution activities coexists with successful export incentives. Using a factor-specific general equilibrium model, he found that the overall impact of protection policies on output of exportable activities could still be substantial. The main reason is that protection results in increases in prices of non-traded goods and in nominal wages, so-called real exchange rate appreciation, reducing the competitiveness of exporters.
} 
firms to establish domestic production in replacement of car imports. In Vietnam, this has been done by imposing high protection on car imports and at the same time, by promoting selfsufficiency in production through local content programs.

The automobile industry is characterized by considerable economies of scale. As is shown in Figure A, the firms face a downward sloping average cost (AC) curve. The high rate of protection on automobiles initially allows automobile makers to sell at high prices at $P_{1}$ and produce at $\mathrm{Q}_{0}$. The initial firms are extremely profitable because of the protection, and this profitability attracts additional entrants. Firms continue to enter until each firm is operating at sub-optimal scale at $\mathrm{Q}_{1}$. Given the strong scale economies prevailing in this industry, the small output level of the firms pushes up their average costs. The rise in average costs eventually eliminates all excess profits and hence removes the incentive for additional firms to enter, until a new equilibrium is reached where excess profits are zero.

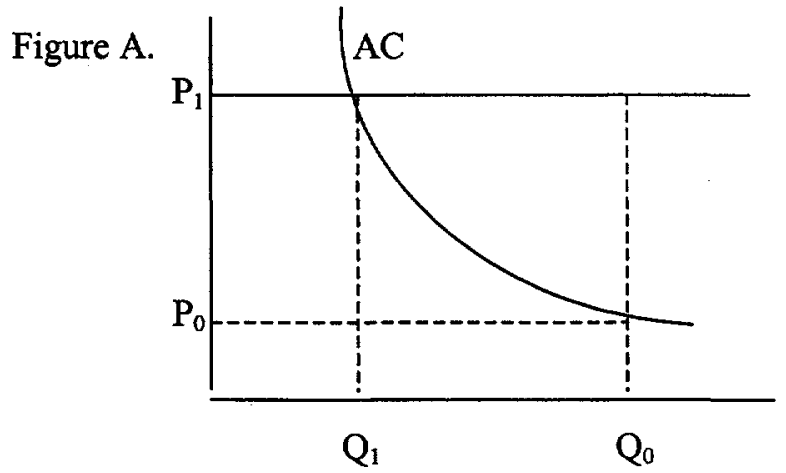

The high rate of protection on automobiles initially attracted fourteen foreign automakers such as Toyota, Ford to set up joint ventures in Vietnam. However, high protection resulted in high production costs rather than high profits.

Vietnam's domestic market is small, which in turn, hampers the achievement of economies of scale. Given the low level of per capita income of $\$ 311$ (around $\$ 1,590$ in purchasing power parity terms in 1997), demand for vehicles is expected to be around 60,000 per year by the year 2,000 (Vietnam Economic Times, May 1997). In addition, a proliferation of models and corresponding fragmentation of production among component suppliers has resulted in small production runs and high costs for many local component suppliers.

The problem is exacerbated by the government's local content policy. In addition to imposing the localization ratio, Vietnam pursues a localization objective through the structure of tariffs and manipulation of quotas on a variety of completely and semi knocked down kits (CKD and SKD) (CIE, 1998). For instance, each approved SKD kit requires that some parts be deleted in order that they might be supplied by local producers, raising the costs of producing the final goods expensive. Such schemes lead to endless political pressure for revision and fragmentation, and frequently lock in production of vehicles using obsolete technology (Pursell, 1999).

These policies are likely to be extremely costly. Consumers lose from the high prices, the government loses potential revenues, while producers lose from sub-optimal scale and high average costs. The industry continues to lobby for further increases in protection given the high costs of production. When it is successful, a short period of increased profitability follows, until the benefits are reduced by additional entry. Then, profits are again at normal levels, and the cycle of lobbying starts over again. 
integrated system of manufacture of exports and products of associated supporting industries, because they discriminate between imports of items for export production and domestic producers of intermediate goods (Flatters, 1998b). For instance, duty draw back system cannot normally compensate 'indirect' exporters who produce inputs for exporters (e.g. domestic textile producers for garments, plastics producer for electronics). ${ }^{12} \mathrm{~A}$ system of high tariffs and deep exemptions, such as is used in Vietnam tends to stimulate exports from assembly-type operations, rather than from sectors with strong forward and backward linkages to other domestic sectors. Under these circumstances, further liberalization can be expected to stimulate the development of exports with a higher proportion of domestic value-added.

\section{III.4. Non Tariff Measures (NTMs)}

A complex set of non-tariff measures is used in Vietnam.

Quantitative restrictions are used to 'regulate supply and demand' and to protect the domestic production of 'potential' and 'infant' industries (WTO, 1998). The regulations on import quota and the list of prohibited imports/exports appear to change from time to time. Circular No. 01/1998TM/XNK stipulates that the following

${ }^{12}$ In Vietnam's garment industry, high import tariffs for protecting import-substitution activities coexist with a relatively successful duty-drawback system for exports. A significant part of imported material for garment industry is brought in through international subcontracting agreements where foreign partners generally provide most of necessary materials as well as designing and marketing functions. This is known as CMT (cut, make and trim). Generally, the value added is low in this kind of business. Since most of the production is targeted at export markets, producers have duty-free access to raw material imports. In contrast, local textile manufactures must bear the costs of import barriers. The discriminatory nature of the duty drawback system hampers integrating local manufactures of textiles into export production of garments. Currently, the industrial linkage of Vietnamese domestic textile and garment sector, between up-stream (fiber production), mid-stream (fabric production and dyeing) and down-stream sector (garment manufacturing) remains very weak. The weak linkage within the 
commodities are subject to import quotas: petroleum, fertilizer, cement, construction glass, paper, sugar, and steel of various kinds (Ministry of Trade, 1998). Following Decision 11/1998/QD-TTg dated January 23, 1998, imports of weapons, antiques, drugs, toxic chemicals, pornographic and reactionary publications, firecrackers, cigarettes, used consumer goods, used spare parts of automobiles are banned. In addition, imports of automobiles and motorcycles of all kinds were not allowed to be imported (as of February 14, 1998). Rice exports are subject to export quotas. The export prohibitions for wood of various kinds and raw rattan apply due to the environmental reasons.

Vietnam's customs valuation is based on the price written on the contract (contract price). For 20 groups of commodities, Vietnam defines minimum prices for import duty valuation (Ministry of Finance, 1998). ${ }^{13} \quad$ The prices for G7 countries and non-G7 countries are differentiated, thus effective tariff rates may be higher for the commodities made in G7 countries. While there are undoubtedly serious problems of understatement in customs values, there is a real risk that such customs valuation rules can lead to large distortions and introduce substantial barriers to trade. For this reason, the GATT rules on Customs valuation involve a strong bias towards the use of invoice prices (WTO 1995).

Price control measures include maximum import pricing and minimum export pricing. The maximum import prices are imposed on large volume imports of certain

textile and garment industry is constraint of expansion of the industry as well as export (Technical Group, Institute of Economics (Vietnam) - IDRC (Canada), 1999).

${ }^{13}$ These include: milk;vegetable oils;food seasoning (monosodium glutamate); sugar and confectionery;beverages;cement;paints;shampoos and soaps;plastics; tires and tubes; papers and boards;sanitary ware and ceramic tiles; construction glass; iron and steel; gas cooker; electric appliances and components;accumulator and battery; automobile; motorcycles and parts; and furniture of various kinds (Ministry of Finance, 1998). 
products such as fertilizer, petroleum, iron and steel, cement, newsprint and writing paper, and certain machinery and equipment. Minimum export prices apply to rice and crude oil (WTO, 1998). It is difficult to determine the extent to which these policies restrict trade. If effective, they are likely to introduce serious distortions and, even if currently ineffective, they introduce a serious problem of nontransparency into the trade regime.

Formal access to foreign exchange is still subject to considerable restriction (CIE, 1998), although the multiple exchange rate regime that prevailed prior to 1989 has been unified. Foreign invested entities are generally responsible for balancing their own foreign exchange requirements. Only entities involved in projects producing specific import substitutes, specified infrastructure projects and designated important projects are guaranteed conversion of local currency.

\section{Nature of AFTA and Vietnam's Liberalization Strategy}

\section{IV.1 Common Effective Preferential Tariff (CEPT) Scheme}

The ASEAN Free Trade Area (AFTA) was formally established in 1992 in order to realize an FTA within 15 years beginning 1 January 1993. The Common Effective Preferential Tariff (CEPT) scheme was designed to bring down tariffs on all manufactured and processed agricultural products to $0-5$ percent within the 15 year timeframe. In September 1994, during the 26th ASEAN Economic Ministers (AEM) Meeting, the time frame was shortened from the original fifteen years to ten years, with the aim of achieving the AFTA goals by the year 2003 (by 2006 for Vietnam and 2008 for 
the Lao PDR and Myanmar). Another important accomplishment of that meeting was to include all unprocessed agricultural products in the CEPT scheme.

Under the CEPT scheme, four lists, -- the Inclusion List (II), the Temporary Exclusion List (TEL), the Sensitive List (SL), and the General Exceptions List (GEL), -are used as key instruments to determine the pace and scope of the liberalization. The $\mathrm{IL}$ consists of the items subject to the tariff reductions immediately to bring them down to the range of 0-5 percent by the year 2003. During the $6^{\text {th }}$ ASEAN Summit in December 1998, the six original ASEAN members agreed to accelerate the implementation of AFTA by one year from 2003 to 2002 for most of the items in the Inclusion List. $^{14}$ The items in the TEL are initially excluded from tariff reductions, but these items are to be transferred to the $\mathrm{IL}$ by 2000 in 5 equal installments beginning from 1996 and then reduced to $0-5$ percent by 2003 . The SL is the list of unprocessed agricultural products and to be phased into the $\amalg$ between 2001-2003 and to be in the $0-5$ percent range by $2010 .^{15}$ In principle, the GEL is intended to consist of items which satisfy Article XX of the GATT (ASEAN Secretariat 1993a). These goods may be permanently excluded from tariff reductions for reasons such as national security, protection of public morals, protection of human, animal and plant life and health, or the protection of articles of artistic, historic or archaeological value.

A key feature of the CEPT is that the concessions are granted on a reciprocal, product by product basis. There are three conditions for a product to be eligible for

\footnotetext{
${ }^{14}$ www.aseansec.org

${ }^{15}$ As of 1996, there were a total 2,025 tariff lines defined as unprocessed agricultural products and they were mapped into three lists: 1,387 tariff lines were in the immediate Inclusion List; 377 tariff lines were in the Temporary Exclusion List and 261 tariff lines were in the Sensitive List (ASEAN Secretariat, 1996).
} 
concessions under the CEPT. 1) The product has to be included in the $I L$ of the both importing and exporting countries; 2) To receive all concessions, the product must have an CEPT tariff of 20 percent or below. If the tariff on a product that a country has included in the CEPT is above 20 percent, then it is eligible for concessions only in those member countries that also impose a CEPT rate that is higher than 20 percent; 3 ) it has to satisfy the local content requirement of 40 percent. In the short-run, the reciprocal nature of the CEPT scheme provides incentives for the member countries to include their commodities in the $\mathrm{IL}$ and to reduce tariffs below 20 percent to receive concessions. The CEPT also involves a phased reduction in tariffs.

Another important feature of the CEPT is that member countries are required to eliminate quantitative restrictions on products on which they receive CEPT concessions, and eliminate other non-tariff barriers within a period of five years after receiving concessions. Based on the UNCTAD classification of NTBs, a working definition of NTBs covers para-tariff measures, price control measures, finance measures, monopolistic measures, and technical measures (ASEAN Secretariat, 1995).

\section{V.2.The liberalization schedules of ASEAN member countries}

In contrast with the former Preferential Trading Arrangement (PTA) scheme, the ASEAN members have made substantial commitments to the AFTA/CEPT scheme in terms of scope and degree of liberalization. Table 4 shows the number of tariff lines that the member countries have included in each list.

Overall, 54,367 tariff lines out of 55,525 lines are either in the IL or TEL. This means that 97.9 percent of tariff lines will be between $0-5$ percent by 2003 (by 2006 for 
Vietnam and 2008 for the Lao PDR and Myanmar). The share of the SL and GEL appears to be small relative to the $I L$ and TEL.

Table 4. CEPT Product Lists

\begin{tabular}{|c|c|c|c|c|c|c|c|c|c|}
\hline \multirow[b]{2}{*}{ Country } & \multicolumn{2}{|c|}{$\mathbf{L}$} & \multicolumn{2}{|c|}{ TEL } & \multicolumn{2}{|c|}{ SL } & \multicolumn{2}{|c|}{ GEL } & \multirow[b]{2}{*}{ Total } \\
\hline & $\begin{array}{l}\text { Tariff } \\
\text { Lines }\end{array}$ & $\begin{array}{c}\text { Share } \\
(\%)\end{array}$ & $\begin{array}{l}\text { Tariff } \\
\text { Lines }\end{array}$ & $\begin{array}{c}\text { Share } \\
(\%)\end{array}$ & $\begin{array}{l}\text { Tariff } \\
\text { Lines }\end{array}$ & $\begin{array}{c}\text { Share } \\
(\%)\end{array}$ & $\begin{array}{l}\text { Tariff } \\
\text { Lines }\end{array}$ & $\begin{array}{c}\text { Share } \\
(\%)\end{array}$ & \\
\hline Brunei & 6105 & 94.0 & 135 & 2.1 & 14 & 0.2 & 239 & 3.7 & 6493 \\
\hline Indonesia & 6622 & 91.8 & 545 & 7.6 & 4 & 0.1 & 45 & 0.6 & 7216 \\
\hline Lao PDR & 533 & 15.0 & 2831 & 79.7 & 96 & 2.7 & 91 & 2.6 & 3551 \\
\hline Malaysia & 8648 & 95.1 & 276 & 3.0 & 104 & 1.1 & 63 & 0.7 & 9091 \\
\hline Myanmar & 2356 & 43.1 & 2987 & 54.6 & 21 & 0.4 & 108 & 2.0 & 5472 \\
\hline Philippines & 5221 & 91.6 & 385 & 6.8 & 68 & 1.2 & 28 & 0.5 & 5702 \\
\hline Singapore & 5739 & 98.0 & 0 & 0.0 & 0 & 0.0 & 120 & 2.0 & 5859 \\
\hline Thailand & 9040 & 99.1 & 79 & 0.9 & 7 & 0.1 & 0 & 0.0 & 9126 \\
\hline \multirow[t]{2}{*}{ Vietnam } & 1718 & 57.0 & 1147 & 38.0 & 23 & 0.8 & 127 & 4.2 & 3015 \\
\hline & 45982 & 82.8 & 8385 & 15.1 & 337 & 0.6 & 821 & 1.5 & 55525 \\
\hline
\end{tabular}

Source: ASEAN Secretariat, CEPT Product Lists (December, 1998)

However, some commodities in the Sensitive and General Exclusion lists represent high trade value and/or high tariff rates. For instance, Indonesia included a high portion of unprocessed agricultural products in the SL including rice, wheat, and soy beans. The 23 tariff lines alone represent about 11 percent of import values from ASEAN. For the new members, the proportions of the GEL are typically higher relative to the other members. For Vietnam and the Lao PDR, for instance, the import values in the GEL correspond to 10 percent and 37 percent of total imports from ASEAN respectively.

Before the ASEAN accession, the new members signed MFN agreements with all the other ASEAN members. ${ }^{16}$ Since the late 1980s, the ASEAN countries have lowered substantially their MFN rates. However, the overall tariff averages mask important

\footnotetext{
${ }^{16}$ MFN status, national treatment, and transparency are the three pre-conditions of the ASEAN accession. These principles are consistent with the WTO.
} 
differences in protection across sectors. Annex 2 shows both simple and weighted tariff averages by sector. There is a general tendency for the protection rates for agricultural commodities and labor intensive industries to be relatively high in the ASEAN countries.

\section{VI.3. Analyses of Vietnam's Liberalization Schedule}

The CEPT Product Lists (December 1998) obtained from the ASEAN Secretariat was analyzed below. Annex 3 summarizes the structure of Vietnam's liberalization schedule. Import and export values obtained from the UNCTAD Trains database (1996) have been assigned to each category in each list. Vietnam's CEPT schedule suggests that 1) revenue implications, 2) export concessions, and 3) the impacts on domestic industries were key criteria in the choice of items to be included in each list.

\section{I) Revenue Implications}

In 1996, Vietnam collected 15.0 trillions in trade tax revenues which represented 5.8 percent of GDP or 24.6 percent of total government revenues (CIE, 1998). Import tax from ASEAN sources are estimated to account for 45 percent of total import tax revenues. Annex 3 shows that the import values corresponding to the $I$, TEL, SL, GEL are estimated to be at 26 percent, 37 percent, 0.04 percent, and 37 percent respectively.

Annex 3 shows that the tariff rates of the items that Vietnam included in the $I L$ are relatively low representing 7.3 percent on an import-weighted average. In contrast, the items in the GEL account for some 37 percent of Vietnam's imports from ASEAN and the average tariff rate on these goods is high at 42.3 percent. This implies that some of the items with high trade volume with high tariff rates are currently excluded from the 
AFTA commitments implying that about 65 percent of tariff revenues from ASEAN are shielded from the CEPT tariff reduction.

\section{2) Export Concession}

On the export side, Annex 3 demonstrates that the share of export values assigned to the $\mathrm{I}, \mathrm{TEL}, \mathrm{SL}, \mathrm{GEL}$ are 63 percent, 36 percent, 0.8 percent, and 0.8 percent respectively. This implies that Vietnam included 99 percent of its export-oriented commodities in the CEPT commitments.

\section{3) Implications on Domestic Industries}

Binding the liberalization schedule with AFTA commitments can be a useful defense against potential protectionism. An announcement that such protection will be reduced under AFTA is likely to encourage import-competing industries to begin adjusting to the changes. For industries in which the current Vietnamese competitiveness is low, such as cement and construction steel, the products are currently in the TEL and the tariffs begin to be reduced in 2003 which is the latest target date for AFTA. ${ }^{17}$ 'Luxury' household appliances such as electric fans, air conditioners, refrigerators and washing machines will begin to be brought down in 2002 or 2003 . Vietnam maintains a policy of encouraging domestic sugar production. The ASEAN agreed to include two sugar items in the Sensitive List. Vietnam will cut tariffs on sugar by 2010 . Furthermore, the announced liberalization is likely to attract export-oriented industries because the availability of low cost intermediate goods and the real exchange rate depreciation facilitate foreign firms to source from the most efficient suppliers.

\footnotetext{
${ }^{17}$ For instance, the current tariff rates for cement and construction steel are 15 percent and 30 percent respectively. Their tariffs begin to phase in 2003 and will be 5 percent in 2006 .
} 
However, a set of commodities including petroleum, cars and other vehicles with less than 15 seats and motor cycles (including in SKD and CKD forms), alcoholic beverages and tobacco, are included in the GEL, and so are currently excluded from the CEPT commitment. The limited scope of AFTA—partly because many of the items are currently excluded from the AFTA commitments and partly because the share of Vietnam's trade with ASEAN is relatively small, suggests that Vietnam should treat AFTA liberalization as an initial step toward broader liberalization rather than as a single undertaking.

In addition to the tariff cuts, Vietnam is required to eliminate quantitative restrictions and other non-tariff barriers under AFTA. Although Vietnam is committed to eliminating licenses and quantitative restrictions, some non-tariff measures have tended to become stronger in recent years (McCarty, 1999).

\section{Modeling Approach}

\section{V.1. Model Structure}

The Global Trade Analyses (GTAP) model is a relatively standard static multisector multi-region Applied General Equilibrium (AGE) model which incorporates the necessary links between factor demands, production structures, trade and protection. The GTAP model is documented comprehensively in Hertel (1997), with updated information on the GTAP web site. ${ }^{18}$ The model assumes that firms use constant returns to scale technology in perfectly competitive product market. Consumption in the household sector is determined by the constant difference of elasticities (CDE) functional form. The

\footnotetext{
${ }^{18}$ www.agecon.purdue.edu/gtap/
} 
equilibrium levels of production and consumption are determined by global demand and supply of the product and zero economic profit for firms. A key assumption of the model is that Vietnamese consumers distinguish between imported and domestic goods, and between imports by country of origin, under the so-called Armington (1969) assumption.

\section{V.2. Theory of Preferential Trade Liberalization}

In this section, we outline the framework used to evaluate the effects of preferential liberalization under AFTA. To do this, we first consider the effects of changes in the rates of protection that Vietnam levies on its imports. Then, we consider the implications of changes in the protection imposed by Vietnam's trading partners.

The impacts of trade liberalization differ between large and small countries. A large country can affect international terms of trade by raising world prices of its imports and by lowering world prices of its exports. In contrast, since a small country cannot influence international terms of trade, it faces world prices in its imports and exports. Since Vietnam is a relatively large economy in some of the products which it trades extensively, we use the large country assumption in this analysis.

The concepts of trade creation and trade diversion are central to the evaluation of discriminatory trade liberalization. Trade creation measures the gains from expanding trade in the products being liberalized. Trade diversion, by contrast, measures the reductions in trade of products disadvantaged by the preferential liberalization. To aid understanding of the concept of trade creation, the market for goods imported from ASEAN is illustrated in Figure 5A. 
Figure 5A. Welfare impacts of Vietnam's liberalization of partner imports

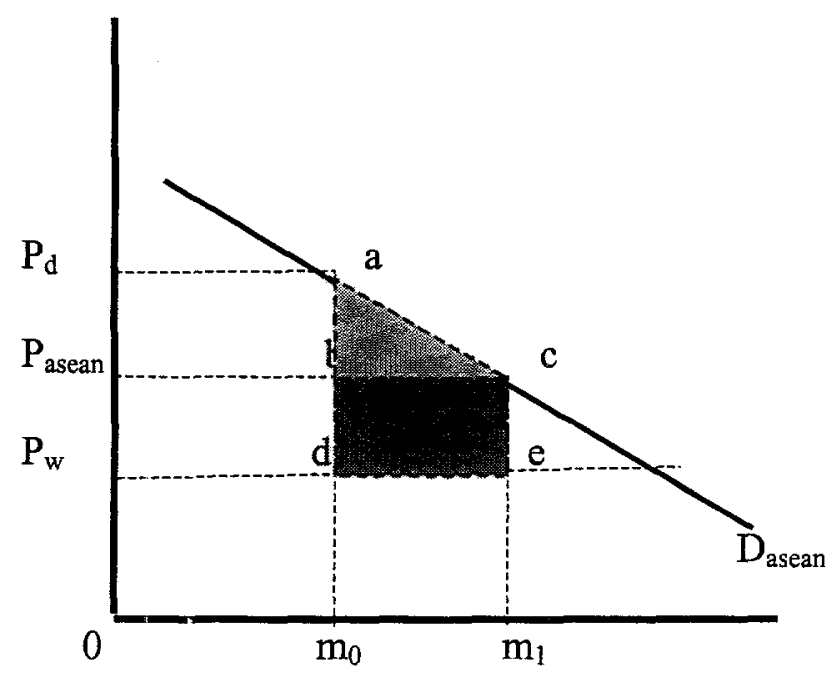

We choose the units of each product so that its world price is unity in the initial equilibrium $\left(\mathrm{P}_{\mathrm{w}}=1\right)$. In the initial equilibrium, Vietnam imposes a tariff $t$ from the ASEAN members $\left(P_{d}=P_{w}+t\right)$. Let us now introduce preferential tariff rate $t_{\text {asean }}$ through a reduction in the tariff on imports from the ASEAN partners. This reduces tariff revenues on initial imports from $\mathrm{ASEAN}$ by $\mathrm{P}_{\mathrm{d}}$ abP $\mathrm{P}_{\text {asean }}$ However, the gains to consumers are greater since they are able to increase the quantity of ASEAN goods that they purchase. Following the decline in the domestic price, consumers move down the (compensated) demand curve for ASEAN goods, $D_{\text {asean }}$ from initial quantity $m_{0}$ to final quantity $\mathrm{m}_{1}$. Consumer surplus increases by the area $\mathrm{P}_{d} a b P_{\text {asean }}+$ abc. In addition, with the increase in the imports from ASEAN, the loss of revenues is partially compensated by the area $b c e d$. In sum, the net gain to Vietnam in this market is approximated by the area aced. This is the welfare benefit from trade creation

If the import distortion being liberalized is the only distortion in the economy, then the welfare impacts of liberalization can be analyzed by considering only the trade creation effects depicted above. If, however, there are distortions in other markets, the 
problem is one of the second best and the impacts of liberalization on the trade flows through these barriers must be considered. Perhaps the best known type of second-best welfare effect is trade diversion. In the analytical framework used in this study, this potential source of loss is readily seen by examining conditions in the market for imports from non-partner countries, represented in Figure 5B.

Figure 5B. Impact of preferential liberalization on imports from non-partner countries.

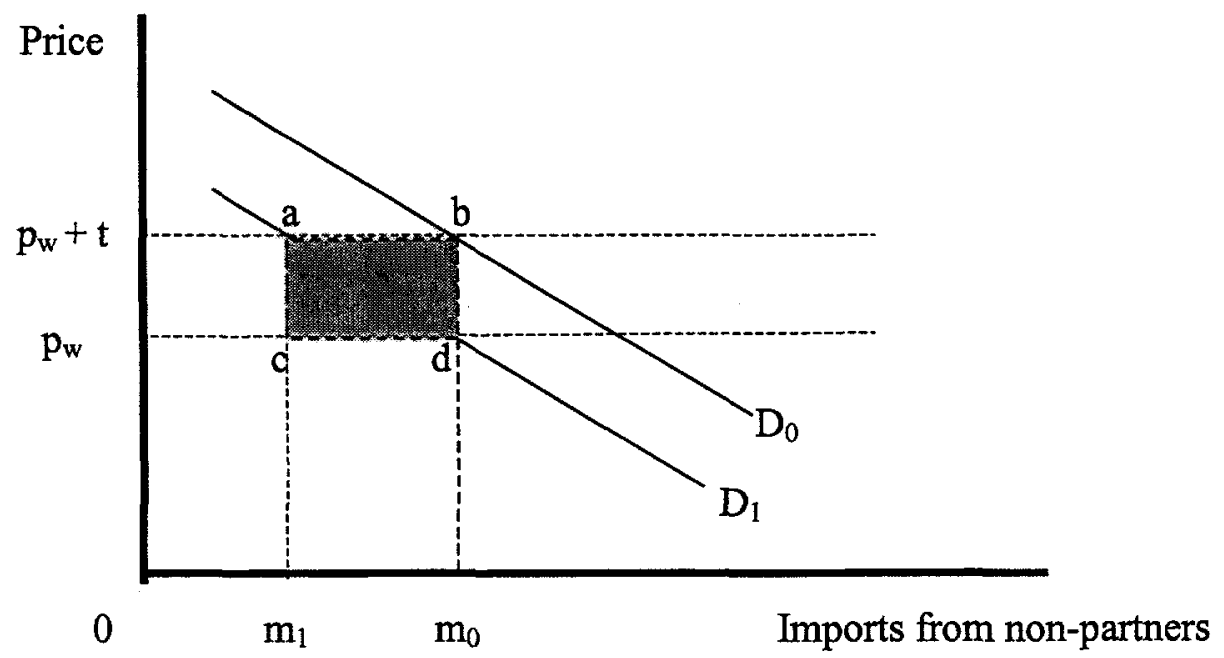

Assuming that imports from non-partner countries are substitutes for imports from partner countries, the reduction in the price of imports from partner countries shown in Figure 5A leads to a reduction in the demand for goods from non-partner countries. This reduction shifts the demand curve for these goods from $D_{0}$ to $D_{1}$. This has adverse welfare consequences that can be measured by the tariff revenues collected on nonpartner imports. This reduction in tariff revenues corresponds to a reduction in welfare because each unit of the good that was previously imported was worth $\mathrm{p}_{\mathrm{d}}$ to consumers in the import market, but cost the country only $p_{w}$ to purchase in world markets. The welfare loss to Vietnam is the loss in tariff revenues, shown by the area $a b d c$. 
Whether there is a net gain or loss to Vietnam depends on the relative sizes of the two shaded areas. Clearly, the gains from trade creation will be larger, the higher the rate of protection initially applied on these trade flows, the more price responsive is the total domestic demand for these goods, (particularly, the more substitutable are domestic and imported goods) and, if the size of the increase in trade is proportional to the initial trade volume, the larger the initial trade volume. Trade diversion costs are likely to be greater the higher the tariffs applied in the non-partner markets and the greater the reduction in the quantity of imports from these markets.

Import liberalization typically brings about an increase in exports by changing the real exchange rate. Lowering the domestic price of at least some imports will cause consumers to substitute these goods for nontraded goods. The reduction in demand for the nontraded good lowers its price relative to the prices of traded goods - - a relative price change frequently termed a real exchange rate depreciation (Salter 1959). This reduction in the profitability of nontraded good production makes production for export relatively more attractive and increases the supply of exports.

The real exchange rate depreciation following import liberalization is represented by a shift in the export supply function from $\mathrm{ES}_{0}$ to $\mathrm{ES}_{1}$ in Figure $5 \mathrm{C}-1$. The outward shift in the export supply curve increases exports from $x_{0}$ to $x_{1}$. If Vietnam's exports have a market power in this market, the increase in exports in turn leads to a deterioration in the terms of trade whose welfare impact is measured by the area $a b c d$. 
Figure 5C-1. Terms of Trade impacts resulting from increased export supply (a large country case)

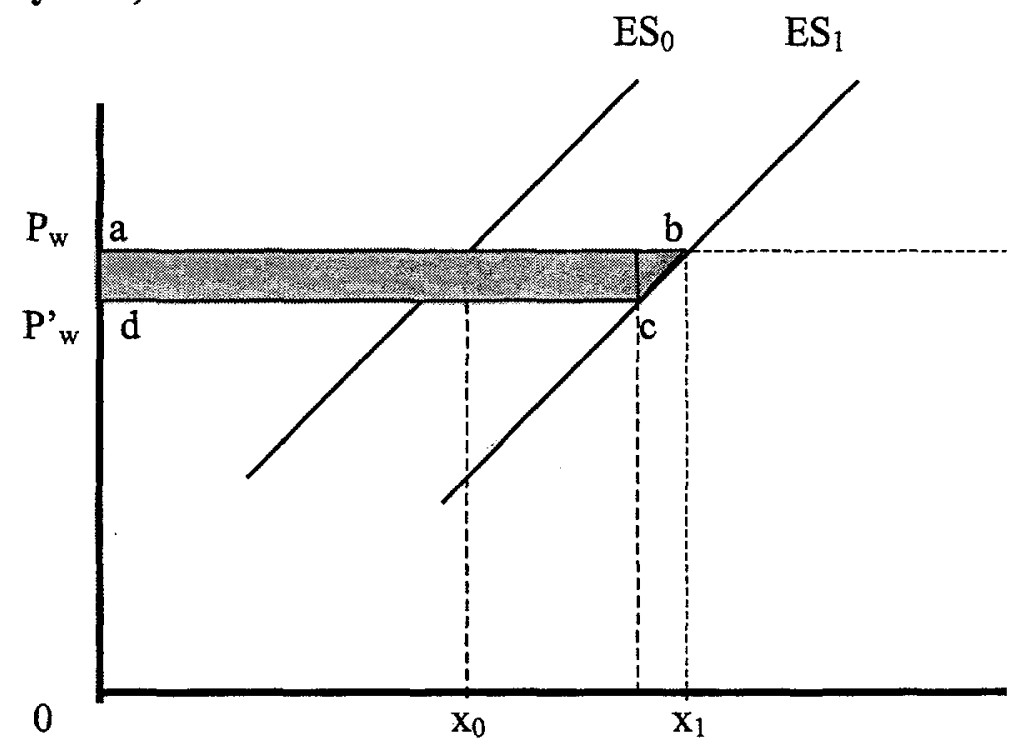

Figure 5C-2. Terms of Trade impacts of improved access to partner markets.

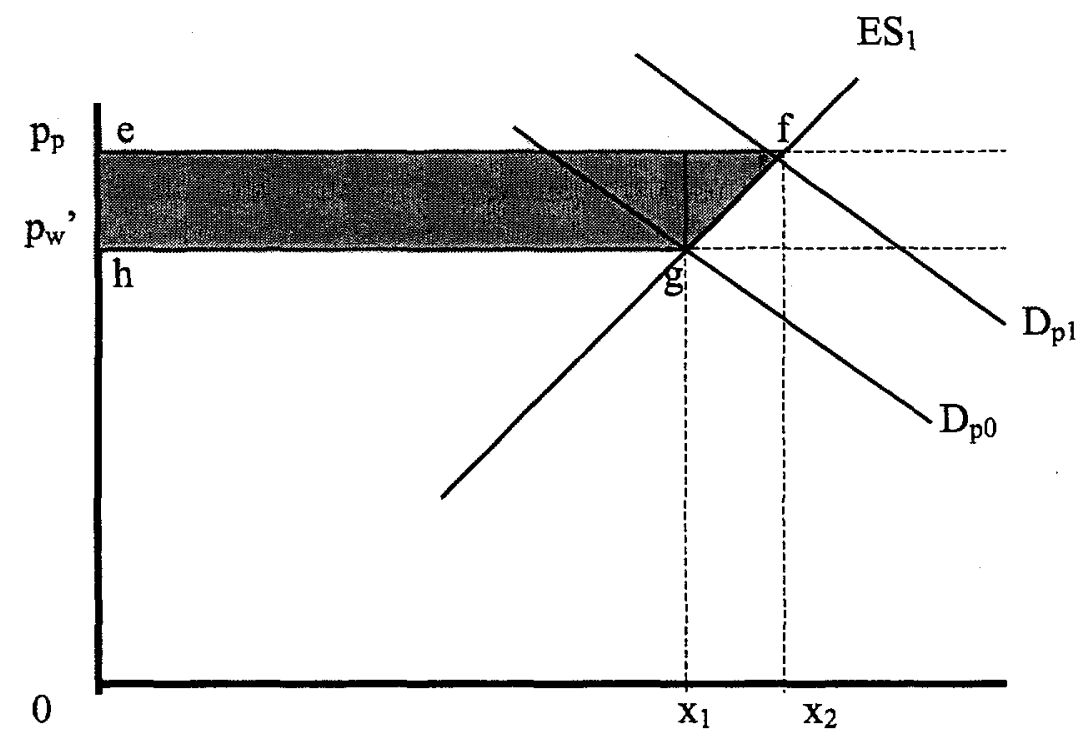

If liberalization in Vietnam results in reciprocal liberalization by Vietnam's trading partners on Vietnam's exports to those partners, then Vietnam will experience a terms of trade gain on the export side. The reduction in the ASEAN partners' tariff on exports from Vietnam shifts the demand curve for exports from $D_{p 0}$ to $D_{p 1}$. In Figure $5 C$ - 
2 , this gain is shown by the move from price $\mathrm{p}_{\mathrm{w}}$ ' to $\mathrm{p}_{\mathrm{p}}$. The result is an increase in both the volume of exports from Vietnam to ASEAN, and an increase in the price received for these exports (shaded area efgh). The net effect of terms of trade depends on the difference between the area $a b c d$ and $e f g h$.

All of the impacts of discriminatory trade liberalization outlined above need to be taken into account simultaneously in forming an overall assessment of the proposed approach. While diagrams of the type shown above aid understanding, they do not provide a practical basis for making an overall evaluation. By contrast, quantitative models allow all of these effects to be taken into account at once.

\section{V.3. Data and Liberalization Shocks}

Particular attention in this study is given to how the changes in relative prices resulting from tariff reductions affect the key variables such as trade patterns, terms of trade, factor returns, and welfare levels. Another focus was given how each policy affects Vietnam's industrial structure. The experiments conducted using the model are comparative-static in nature and we do not directly consider the effects of this liberalization on growth rates nor the 'natural' growth of trade which would occur without further liberalization.

The protection levels that the ASEAN-5 apply to each other are set at the level of 2003, being already reduced to reflect reciprocal concessions. The shocks to be calculated are the reduction of tariff under the AFTA plan both by Vietnam against ASEAN 5 and by the ASEAN 5 countries against Vietnam. Vietnam's tariff schedule (February, 1998) was obtained from the Centre for International Economics to compute MFN tariff rates and the tariff reductions agreed under AFTA were obtained from the 
CEPT Product List (ASEAN Secretariat, 1997/1998). Taking into account the 'reciprocal' concessions, the bilateral concessional tariff rates were computed item by item bases at the 6-digit level for ASEAN 5 and 4-digit level for Vietnam and then averaged over 13 aggregated categories.

Given the importance of Vietnam's trade with APEC countries, an additional simulation was designed to investigate what happens if Vietnam and the other APEC countries liberalize simultaneously under the APEC framework. Unlike AFTA, APEC trade liberalization is based, in principle, on a unilateral and non-discriminatory basis. ${ }^{19}$ As a very rough hypothetical scenario, we investigate what happens if all the APEC member countries reduce tariffs to 2.5 percent on an MFN basis. Since the timeframe of liberalization under APEC is different from AFTA (2010 for industrialized economies and 2020 for developing economies), and APEC commitments are not binding in the same way as AFTA, the scenario should not be viewed as reflecting the commitments of the APEC member countries. Rather, APEC simulation is aimed to have a preliminary idea on what happens if all the APEC members liberalize unilaterally on a nondiscriminatory basis.

The simulations are summarized as below.

\footnotetext{
${ }^{19}$ At their meeting in Bogor in 1994, the goal was set to realize a free and open trade and investment area in the Asia-Pacific region no later than 2010 for industrialized economies and 2020 for developing economies. At Subic Bay in 1996, APEC entered its action phase with the adoption of the Manila Actin Plan for APEC (MAPA). The three pillars of the MAPA are Individual Action Plans (IAPs), Collective Action (CAPs), and Joint Activities in Economic and Technical Cooperation. The IAPs are voluntary submissions of unilateral liberalization initiatives by member economies. The CAPs are the collective action plans which are agreed upon through the process of consensus. The third component of the MAPA is based on the principle that trade and investment liberalization and facilitation should be supported and complemented by economic and technical cooperation (Manila Action Plan for APEC, 1996).
} 


\section{Experimental Design}

Scenario 1 (AFTA1): Inclusion List (IL) and Temporary Exclusion List (TEL) liberalization under AFTA (2003 for ASEAN 5 and 2006 for Vietnam). Vietnam liberalizes the items in the IL and TEL. ASEAN-5 members reciprocate the concessions.

Scenario 2 (AFTA2): Scenario 1 plus Sensitive List (SL) liberalization (2010 for ASEAN 5 and 2013 for Vietnam). Vietnam liberalizes the items in the IL, TEL, SL and ASEAN-5 members reciprocate the concessions.

Scenario 3 (AFTA3): Scenario 2 plus General Exception List (GEL) liberalization. Vietnam liberalizes, as a counterfactual, the items in the IL, TEL, SL and GEL. The ASEAN-5 members reciprocate the concessions.

Scenario 4 (UNILATERAL): Scenario 3 plus unilateral tariff reduction on a nondiscriminatory basis. We investigate what happens if Vietnam extends its AFTA concessions to

the rest of the world. We assume that the other APEC members maintain the current protections.

Scenario 5 (APEC): All the APEC members, including Vietnam, reduce their tariff rates unilaterally to 2.5 percent on a non-discriminatory basis.

\section{V.4. Results}

\section{1) Direction of Trade}

Annex Tables 5A and 5B show how the directions of trade change with the AFTA and APEC simulations. When Vietnam liberalizes the Inclusion List (IL) and the Temporary Exclusion List (TEL), its imports from ASEAN increase whereas imports from the rest of the world decrease. Imports from Indonesia, Malaysia, the Philippines, Singapore, and Thailand increase by 26 percent, 50 percent, 19 percent, 24 percent and 60 percent respectively. On the export side (Annex 5B), exports to ASEAN increase with the exception of Singapore whereas the export values to the rest of the world are relatively unchanged. Increases in exports to Thailand are especially high registering a 97 
percent increase because of the substantial tariff cuts given by Thailand on its imports from Vietnam. In contrast, exports to Singapore are unchanged since the initial tariff rates of Singapore are close to zero.

The second tables in Annex 5-A and Annex 5-B refer to the results of the Sensitive List (agricultural goods) liberalization in addition to the $\mathbb{L}$ and $T E L$ liberalization. Whereas the SL liberalization affects the import side relatively little, exports to Malaysia and the Philippines increase substantially. This is because Malaysia and the Philippines included some important items such as processed rice in the Sensitive List (SL).

The third set of tables demonstrates the results of General Exception List (GEL) liberalization in addition to the $\mathbb{I}, \mathrm{TEL}$, and the SL liberalizations. In principle, products in the GEL are permanently excluded from the CEPT scheme. However, since Vietnam included a range of commodities that goes far beyond the usual interpretation of this category, such as alcoholic beverages, motorcars, motorcycles and petroleum products, a simulation was conducted to test, as a counterfactual, what happens if Vietnam liberalizes the products in the GEL. Imports from Singapore and Thailand increase substantially from $\$ 2069$ to $\$ 2461$ million for Singapore and $\$ 795$ to $\$ 1130$ million for Thailand. The increase in imports of beverage and tobacco (BTP) and petroleum products (PCP) from Singapore and increase in imports of transport equipment (TRP) from Thailand contribute to these changes. On the export side, the liberalization of GEL affects the exports to ASEAN relatively little since the products in the GEL are not export-oriented products. However, overall exports increase in order to finance increased imports. 
The fourth set of tables in Annex 5-A and B (Scenario 4) shows what happens if Vietnam liberalizes all the lists under AFTA and then extends the same liberalization to the rest of the world. Imports are now sourced from a wider variety of countries and exports to EU15 and Japan increase noticeably relative to AFTA liberalization. These owe mainly to the increase in clothing sector which increases by 85 percent and 83 percent respectively. This is perhaps because of increased access to cheaper imports of raw materials, as shown in increases in imports in textiles from China, NIEs and Japan, will lower the cost of clothing production.

\section{2) Effects on Outputs}

Unilateral liberalization has two offsetting effects on output levels. On the one hand, reductions in the costs of intermediate inputs create beneficial forward linkages to domestic production and promote industrialization (Puga and Venables, 1998). On the other hand, more intense import competition has an adverse effect on the profitability of import-competing firms. Table 5 refers to the effects on output.

Table 5. The Effects on Output

\begin{tabular}{|ll|ccccc|}
\hline & & Scenario 1 & Scenario 2 & Scenario 3 & Scenario 4 & Scenario 5 \\
\hline & & AFTA 1 & AFTA 2 & $\underline{\text { AFTA 3 }}$ & $\underline{\text { Unilateral }}$ & APEC \\
AGR & Agriculture and forestry & $(\%)$ & $(\%)$ & $(\%)$ & $(\%)$ & -4 \\
PAG & Processed agriculture & -0.1 & 0.2 & 0.3 & -1.9 & -22.7 \\
BTP & Beverage and tobacco & -1.2 & 7.8 & 8.7 & 2.5 & -53.8 \\
COG & Coal, oil, gas & -0.1 & -1 & -47.0 & -55.0 & 1.2 \\
PCP & Petroleum products & -0.1 & -0.3 & 1.4 & 0.5 & 13.8 \\
TEX & Textiles & 5 & 5 & 5.8 & 1.7 & 16.4 \\
CLO & Apparel & 2.6 & 0.2 & 7.9 & 75.4 & 83.9 \\
LMF & Light manufacturing & 10.1 & 6.9 & 3.3 & 15.6 & 28 \\
BMF & Basic manufacturing & 4.2 & 1.9 & -3.7 & -12.8 & -10.9 \\
CRP & Chemical, rubber, plastics & -3.6 & -4.6 & -1.0 & -2.6 & 0.1 \\
TRP & Transport equipment & -0.4 & -1 & -31.5 & -48.1 & -54.2 \\
MCE & Electronics and machinery & -3.6 & -2.6 & -2.8 & -7.5 & -5.2 \\
\hline
\end{tabular}

Source: Authors' Simulation Results (qo) 
The outputs of agriculture, forestry (AGR), and processed agriculture (PAG) increase with AFTA liberalization, especially with the Sensitive List (SL) liberalization, whereas the outputs of these sectors decrease when Vietnam extends the concession to the rest of the world. In particular, the decrease in output of processed agriculture (PAG) by 23 percent under APEC liberalization is worth noting. ${ }^{20}$ This appears to be because agricultural processing industries in many countries were adversely affected by protection on their raw agricultural inputs. With widespread liberalization, agricultural processing in these countries expands, placing competitive pressure on the agricultural processing in Vietnam. As the profitability of agricultural processing falls in Vietnam due to the increasing competition, Vietnamese labor and other resources move to the now more profitable labor intensive sectors such as clothing and light manufacturing, whose expansion is stimulated by the increased market access to the APEC countries.

There is very substantial expansion of apparel industry particularly when Vietnam liberalizes against the rest of the world either unilaterally or in the APEC. This is partly because low cost intermediates resulting from import liberalization lowers the cost of production $^{21}$; partly because Vietnam has a clear comparative advantage in the laborintensive sectors against non-ASEAN countries whereas its competitive position for these commodities is less clear within ASEAN.

\footnotetext{
${ }^{20}$ Since the APEC scenario is hypothetical, the results should not be considered as rigorous estimates. However, the results shed some lights on the qualitative assessments of the APEC liberalization. On the one hand, the APEC-wide liberalization introduces competition in Vietnam's exports. On the other hand, Vietnam is likely to benefit from the increased access to the APEC markets.

${ }^{21}$ Currently, Vietnam's textile and garment industry has to import most of raw materials from abroad. However, this result is likely to be overestimating the magnitude of expansion since many firms benefit from duty drawback system.
} 
In contrast, the outputs of some import competing sectors are likely to contract due to increasing competition. In particular, transport equipment (TRP) and beverage and tobacco sectors (BTP) contract if Vietnam liberalizes those items currently in the GEL of the CEPT Scheme (scenario 3) and further contracts if Vietnam liberalizes against the rest of the world. The impacts on the basic manufacturing (BMF) ${ }^{22}$ appear to be relatively small under AFTA whereas the production contracts further with a non-discriminatory liberalization.

\section{3) The Effects on Factor Returns}

A regional integration makes trade easier and hence tends to raise the returns to at least some factors of production (Winters, 1996). A simple application of the HeckscherOhlin model might lead us to expect Vietnam's returns to capital to fall since Vietnam is capital-scarce relative to its ASEAN partner countries. Since international trade tends to increase the returns to the abundant factor and reduce those to the scarce factor, assuming protection against capital intensive goods from ASEAN, increased trade with ASEAN might be expected to reduce the returns to capital in the new members. However, there is a number of reasons to believe that the basic Heckscher-Ohlin model is too simple for our purposes and one might expect ASEAN to raise the rates of returns on capital in both partners regardless of capital abundance.

First, the standard Heckscher-Ohlin model applies only to a so-called square model with equal numbers of factors of production and goods; and there is no indication

\footnotetext{
${ }^{22}$ Some important industries such as cement, paper, and steel, belong to this category. However, caution should be borne in mind to interpret this result since our simulation does not include protective effects of quantitative restrictions. For these industries, the main protection measures are nontariffs such as quota and market entry.
} 
that this is the way the real world is. The GTAP 4 database identifies five factors of production: land, unskilled labor, skilled labor, capital, and natural resources and up to 50 commodities. Second, the Heckscher-Ohlin model presumes homogeneous products, whereas experience suggests that many markets are better represented by differentiated products and intra-industry trade. The GTAP model assumes the so-called Armington assumption with the goods being differentiated by country of origin. In addition, the substitutability of domestic and foreign goods also becomes very important. Third, integration might affect the rate of return on capital through the price of intermediate and capital goods. A reduction in tariffs and trading costs on imports of capital equipment will reduce the prices which industry has to pay for investment goods (The model does not capture this effect directly because the total stock of capital in each country is fixed in these simulations).

Table 6 shows the simulation results of the changes in returns to the factors of production. The measure reported reflects the changes in factor prices relative to the price index for private consumption expenditure. It does not, however, take into account the effects of changes in the revenue position of the government, and its ability to redistribute tax revenues to individuals, either through transfers or the provision of public goods.

Table 6. Real Returns to Factors of Production

\begin{tabular}{|l|ccccc|}
\hline & Scenario 1 & Scenario 2 & Scenario 3 & Scenario 5 & Scenario 6 \\
\hline & $\underline{\text { AFTA 1 }}$ & $\underline{\text { AFTA 2 }}$ & $\underline{\text { AFTA 3 }}$ & Unilateral & APEC \\
Land & $(\%)$ & $(\%)$ & $(\%)$ & $(\%)$ & $(\%)$ \\
Unskilled Labor & 1.9 & 4.0 & 9.9 & 2.9 & -8.3 \\
Skilled Labor & 2.3 & 2.7 & 8.0 & 16.1 & 17.2 \\
Capital & 2.0 & 2.4 & 7.7 & 15.4 & 17.7 \\
Capital & 2.0 & 2.4 & 7.2 & 14.3 & 16.0 \\
\hline
\end{tabular}

Source: Authors' Simulation Results (pfactreal) 
AFTA raises real wages for both skilled and unskilled labor as well as the return to capital. The magnitude of increases more than doubles when Vietnam extends its liberalization against the rest of the world. Returns to land increase under AFTA liberalization whereas its return decreases with non-discriminatory liberalization. Again, this is because Vietnam has a comparative advantage in agriculture among the ASEAN countries. With further liberalization with the rest of the world, since land is a sector specific and labor is spectrally mobile, a portion of labor appear to shift from the agricultural sector to industrial sectors. In sum, a wider scope of Vietnam's liberalization is likely to induce Vietnam's industrialization.

\section{4) Terms of Trade}

The terms of trade, which is usually defined as the ratio of the region's export price to import price, is a key concept in evaluating the effects of price changes on welfare. The reciprocal liberalization involved in AFTA leads to two offsetting effects. (i) Liberalization of Vietnam's imports reduces costs in Vietnam and hence increases its supply into world markets. This, in turn, can be expected to reduce the prices received for exports per unit. (ii) As its AFTA partners reduce their tariffs on Vietnamese exports, their demands for Vietnamese exports rise, and this in turn improves Vietnamese export prices (see Figure 5C-1,2). The net. effect depends on which effect is larger. Table 7 demonstrates the effects on the terms of trade. ${ }^{23}$ Table 7 implies that Vietnam's terms of

\footnotetext{
${ }^{23}$ We follow McDougall (1993) to decompose the impact of terms of trade into three components: the world price effect (1), the export price effect (2), and the import price effect (3).

Terms of Trade
} 
trade deteriorate primarily through changes in its export prices with the exception of scenario 2. Most of the terms of trade deterioration results from falls in the prices received for exports, but a part results from increases in the prices of imports. The larger magnitude in change in export prices relative to import prices is related to the assumption of the product differentiation by country of origin (e.g. Vietnamese rice, Japanese cars) on the demand side, a standard feature of the Armington (1969) model. With the standard GTAP elasticities of substitution that we have used in this paper, increases in Vietnam's export supplies require falls in the prices of Vietnamese exports if Vietnam is to increase its export share. On the import side, Vietnam faces highly elastic export supplies curves because of its small size of the economy. Thus, Vietnam needs to pay higher prices for its imports only to the extent that it is a relatively large importer from world markets.

The improvement in the terms of trade in scenario 2 reflects the increases in export prices resulting from the ASEAN partners' concessions against Vietnam's

$T=\Sigma \Delta T_{1 i}+\sum \Delta T_{2 i}-\Sigma \Delta T_{3 i}$

(1) World Price Effect: $\Delta T_{l i}=\left(S_{x i}-S_{m i}\right) *\left(P_{w i}-P_{w}\right)$

(2) Export Price Effect: $\Delta T_{2 i}=S_{x i} *\left(p_{x i}-p_{w i}\right)$

(3) Import Price Effect: $\Delta T_{3 i}=S_{m i} *\left(p_{m i}-p_{w i}\right)$

The world price effect (1) equals the sum over all traded commodities of a country's net trade share (the difference between export and import shares) for good i $\left(S_{x i}-S_{m i}\right)$ and the change in the price of i $\left(P_{w i}\right)$ relative to an index of average world prices $\left(P_{w i}-P_{w}\right)$. In a perfect substitute model, (1) would fully account for the change in terms of trade since each commodity has a single world price. In an imperfect substitute model, changes in terms of trade can also arise from changes in the relative prices of different source-specific varieties of the same commodity. The export price effect (2) refers to the sum of export share-weighted, relative price changes, where the relative price in question is the ratio of the exporter's price for commodity i $\left(p_{x i}\right)$ relative to the worldwide average $\left(p_{w i}\right)$. The degree to which these two prices can diverge is a function of the extent of product differentiation in market $i$. The import price effect (3) is the import share-weighted change in the country specific price index $\left(P_{w_{i}}\right)$ relative to the average world price $\left(p_{w i}\right)$. 
agricultural commodities, which are particularly important for Vietnam given its revealed comparative advantage in agriculture within ASEAN.

Table 7. The Effects of Terms of Trade

\begin{tabular}{|l|ccccc|}
\hline & Scenario 1 & Scenario 2 & Scenario 3 & Scenario 4 & Scenario 5 \\
\hline & $\frac{\text { AFTA 1 }}{(\%)}$ & $\frac{\text { AFTA 2 }}{(\%)}$ & $\frac{\text { AFTA 3 }}{(\%)}$ & $\frac{\text { Unilateral }}{(\%)}$ & $\underline{\text { APEC }}$ \\
World Price Effect & 0.00 & 0.00 & 0.00 & -0.01 & 0.01 \\
Export Price Effect & -0.2 & 0.4 & -0.4 & -0.7 & -2.6 \\
Import Price Effect & 0.02 & 0.02 & 0.05 & 0.02 & -1.1 \\
Total TOT Effects & -0.2 & 0.4 & -0.4 & -0.7 & -1.5 \\
\hline
\end{tabular}

Source: Authors' Simulation Results (c1 r, c2 r, c3 r, tot2)

In contrast, the terms of trade impacts are negative under scenario 3 , because Vietnam gains very little from improved access for these products to partner countries, its increased exports tend to depress its export returns, and it must pay higher prices to source more imports from its ASEAN partners as Vietnam increases its demand for imports from these countries alone.

Under Unilateral liberalization, the deterioration in the export prices of Vietnamese goods is larger than under the AFTA liberalization scenarios because Vietnam is liberalizing more, and hence increasing its competitiveness and exports by more than under the AFTA scenario. The decline in prices is likely to be particularly large relative to world prices for commodities in which Vietnam greatly expands its export volumes.

\section{5) Economywide Effects}

Table 8 presents the key results for some important economy-wide variables.

As the scope of liberalization widens from partial AFTA to non-discriminatory, both imports and exports increase. With scenario 2, Vietnam's imports and exports increase by 3.1 percent and 3.9 percent respectively. The magnitude of increase in trade value is 
the highest with the non-discriminatory liberalization (scenario 4) which implies 12.8 percent increase in imports and a 15.2 percent increase in exports. The increases in the value of trade as we move from scenario 1 to scenario 4 in Table 8 reflect favorable impacts of increases in export volumes, and unfavorable impacts of declines in export prices $^{24}$ as export volumes increase-clearly, the export volume impacts dominate overall. However, values of trade under APEC (scenario 5) decrease slightly relative to scenario 4, reflecting falling prices. The increase in export volumes, which is more relevant than values to the question of employment in the export sector, would be substantially greater at 13.6 percent (not reported) under APEC than unilateral liberalization at 12.7 percent.

Table 8. Key Economywide Variables for Vietnam

\begin{tabular}{|l|cccccc|}
\hline & Scenario 1 & Scenario 2 & Scenario 3 & Scenario 4 & Scenario 5 \\
\hline & AFTA 1 & $\frac{\text { AFTA 2 }}{3.1}$ & $\frac{\text { AFTA 3 }}{6.4}$ & $\underline{\text { Unilateral }}$ & APEC \\
Total Import Value (\%) & 32.8 & 33.4 & 63.3 & 12.8 & 11.7 \\
$\quad$ From ASEAN & -12.3 & -12.1 & -23.1 & 7.5 & 3.9 \\
$\quad$ From ROW & & & & & \\
& 3.9 & 4.7 & 7.2 & 15.2 & 12.7 \\
Total Export Value (\%) & 13.8 & 33.6 & 36.9 & 33.8 & -2.6 \\
$\quad$ To ASEAN & 2.3 & 0.1 & 2.5 & 12.2 & 15.2 \\
$\quad$ To ROW & & & & & \\
& -18.0 & -17.8 & -56.0 & -82.4 & -84.7 \\
Tariff Revenue (\%) & & & & & \\
& 0.02 & 0.4 & -0.04 & 1.4 & 1.3 \\
Real Expenditure (\%) & 2.1 & 51.3 & -5.6 & 191.6 & 180.3 \\
Total EV (\$mil.) of which & 19.2 & 21.7 & 26.6 & 251.0 & 293.3 \\
$\quad$ Allocative Component & -17.1 & 29.6 & -32.3 & -59.4 & -113.0 \\
\hline Terms of Trade Component & &
\end{tabular}

Source: Authors' Simulation results (VIW, CNTalleffr, CNTtotr)

\footnotetext{
${ }^{24}$ Throughout this analysis, we have utilized the default values of the Armington trade elasticities from the GTAP database. There is considerable evidence that these values are too low for long-run simulations such as those undertaken here, and many simulations of long run liberalization (see Martin and Winters 1996, for example) utilize substantially higher values, which result in much smaller terms of trade deteriorations when countries liberalize.
} 
On the import side, liberalization directly stimulates increases in imports of those goods subject to liberalization. Where liberalization is discriminatory, as is the case with AFTA, part of the increase in imports from partner countries is offset by reductions in imports from other countries (trade diversion). For instance, under scenario 2, which is the current scenario under AFTA, imports from ASEAN increase by 33.4 percent, while imports from the rest of the world clecrease by 12.1 percent. Larger increases in imports from ASEAN relative to the rest of the world under non-discriminatory liberalization (scenario 4) may reflect the higher initial tariff rates against ASEAN imports. ${ }^{25}$ The broader the geographic coverage of import liberalization, the greater the overall stimulus to imports (trade creation), and the greater the associated stimulus to exports. Under the APEC liberalization scenario, exports to the rest of the world increase by 15.2 percent whereas those to ASEAN decrease slightly. This is due to the increased market access resulting from the liberalization by the APEC countries whereas the gains from market access within ASEAN are relatively small because of the dominance of Singapore in Vietnam's exports.

There are losses of tariff revenue ranging from 18.0 percent in scenario 2 to 82.4 percent in scenario 4. The loss of tariff revenues is smaller in scenario 2 than in scenario 3 since the increased imports financed by increased exports outweigh the loss resulting from tariff reduction. The change in tariff revenues under discriminatory liberalization

\footnotetext{
${ }^{25}$ While the tariff rates are the same at the tariff line level, the weighted averages differ because of the differences in the mix of imports in each commodity group. The higher initial tariff rates against ASEAN countries imply that the commodity composition sourced from ASEAN consists of the items with relatively high tariff rates. Average tariffs differ between ASEAN and the rest of the world, with duties on imports form ASEAN averaging 24.3 percent as against 16.5 percent from the rest of the world.
} 
has three components. These are (i) a loss of revenues resulting from the fall in rates on the goods liberalized; (ii) a gain from increases in the volumes of liberalized imports; and (iii) a loss of revenues from reductions in the volumes of import flows not being liberalized. The third loss reflects the problem of trade diversion and is frequently critical to the welfare impacts of discriminatory liberalization.

The overall welfare effects presented in Table 8 reflect primarily the consequences of the allocative efficiency effects of liberalization and trade diversion, and terms of trade effects. In scenario 1 , the overall welfare gain is close to zero since the gains resulting from increased trade with the ASEAN partner countries are offset by the trade diversion from the rest of the world, which causes a loss of tariff revenues. The net welfare gain from the regional liberalization is more or less completely offset by the overall deterioration in the terms of trade.

Under scenario 2, Vietnam's real expenditure increases by $\$ 51.3$ million per year, or 0.4 percent of base-period expenditure. This gain is primarily attributed to the terms of trade gains against Vietnam's agricultural goods resulting from the concession given by ASEAN partner countries.

Under scenario 3 , the net welfare gains are very slightly negative. The net gains in allocative efficiency resulting from the regional liberalization are very small because of the trade diversion towards ASEAN partners. The negative terms of trade impacts more or less completely outweigh the positive allocative effects.

Under scenarios 4 and 5 , real expenditure increases substantially by 1.4 percent and 1.3 percentage points from the baseline, more than tripling the real gains from AFTA liberalization. Although Vietnam experiences larger terms of trade deterioration in its 
exports, the loss is far outweighed by the improved resource allocation impacts. Part of this is because these types of unilateral liberalization unwind the welfare losses arising from trade diversion created by the regional arrangement. Following these unilateral liberalizations, Vietnamese firms can choose to source from lower cost suppliers than those available in the ASEAN group. Part of this is because available resources are more efficiently used among different industries.

Allocative efficiency is the highest under scenario 5. Since tariff reductions are nondiscriminatory under APEC, there can be no trade diversion. However, the welfare level is slightly lower relative to scenario 4 due to the deteriorating terms of trade.

\section{Concluding Remarks}

AFTA is an important initial step for Vietnam's further liberalization. Under it, Vietnam must commit to a tariff reduction schedule at the tariff line level and starts to identify and eliminate quantitative restrictions. This process involves harmonizing tariff nomenclature, improving legal and regulatory frameworks, and facing the needs of increasing competitiveness of its industries. AFTA is a useful training ground for Vietnam's integration into a global economy.

However, our simulation results showed that the static economy-wide effects of AFTA liberalization currently committed to by Vietnam are relatively small. There are several important reasons for this. On the import side, the share of imports from AFTA partners is currently relatively small, and the initial extent of liberalization of these imports is also limited. In addition, the gains from trade creation are offset by the costly trade diversion resulting in the form of loss of tariff revenue from non-ASEAN countries. On the export side, the dominance of Singapore in Vietnam's ASEAN exports implies 
relatively small gains from the increase in market access, since Singapore's initial protection is already close to zero. Further, the standard GTAP model used in the analysis suggests that there may be significant terms of trade losses from the export expansion associated with the AFTA liberalization.

All of above suggests that it is beneficial for Vietnam to extend its AFTA concession on an MFN base. When Vietnam extends its AFTA commitments to all of its trading partners, Vietnam's welfare increases substantially. These gains are larger in part because of the greater extent of liberalization, and in part because the broader liberalization undoes the costly trade diversion created by the initial, discriminatory, liberalization, and finally due to the more efficient allocation of resources among Vietnam's industries.

The simulation results reveal that AFTA, unilateral and APEC liberalizations affect Vietnam's industries in different ways. AFTA appears to have beneficial impacts on Vietnam's agriculture resulting from the increasing access to ASEAN market, especially with the Sensitive List (SL) liberalization. In contrast, a broader liberalization beyond AFTA is likely to cause a shift of labor from agriculture and a set of import competing activities towards relatively labor-intensive manufacturing. These sectors conform to Vietnam's current comparative advantage and taking this step now seems a promising way to facilitate the subsequent development of competitive firms in more capital and skill intensive sectors.

In contrast, some import competing industries, including transport equipment and beverages, tend to contract with wider liberalization, revealing the dependance on protection of these industries. Whether or not to protect so-called key industries is 
controversial. If the gains from 'learning by doing' in these industries are high enough, then such an import substitution policy might increase growth rates even while foregoing some of the gains from comparative advantage. However, as the experience of some Asian countries revealed in the recent financial crises, the industries developed behind high protective barriers and vested interests tend to remain inefficient and impose substantial costs to the economy.

Despite substantial progress since Doi Moi, Vietnam remains one of the most distorted economies in the region. The state sector still enjoys various forms of privileges including access to land, capital, and quota allocations. In particular, import substitution policy has been applied to promote a set of capital-intensive and strategic industries, which are often run by joint ventures between SOEs and foreign firms, and high protection is used to attract foreign investments. Preferential treatments of these industries impose implicit tax on small and medium private sectors, which are usually labor-intensive. Vietnam appears to employ a set of export promotion measures such as duty drawback system to mitigate negative effects of protection on export sectors. However, a system of high tariffs and deep exemptions tends to stimulate exports from assembly-type operations, rather than from sectors with strong forward and backward linkages to other domestic sectors. Binding international commitments in AFTA and, in due course, at the WTO, provide a credible signal of Vietnam's commitment to open trade policies that will help stimulate upgrading of existing firms and investment in efficient and dynamic new firms.

Industrialization and modernization should be built on the development of the skills needed for modern industrial development and on the improvement of physical and 
institutional infrastructures. The opportunity for Vietnam to expand the labor-intensive manufacturing sectors that so well match its current pattern of factor endowments may be an important step on the ladder of development. This step provides a platform for the progressive development of more capital and skill intensive sectors as long as sufficient attention is paid to the accumulation of the human and physical capital needed for the expansion of these sectors.

Finally, the multi-region and multi-sector modeling framework adopted in this study has proved to be a useful tool to assess the simultaneous impacts of trade liberalization by Vietnam and its trading partners on trade, output, and welfare. However, the model is subject to a number of limitations. First, the model is static and it does not take into account the dynamic effects of trade liberalization which would occur during the phase-in period. ${ }^{26}$ Second, we did not address the protective effects of Non Tariff Barriers (NTBs) for want of adequate information on their restrictiveness. If NTBs were incorporated in the model, the magnitude of consequences of trade liberalization would be larger. Third, we have not been able, to date, to analyze the set of export promotion measures such as the duty drawback system which coexist with the import protection.

\footnotetext{
${ }^{26}$ For the survey of potential dynamic benefits of ASEAN/AFTA Accession, see Fukase and Winters (1999).
} 


\section{References}

Amsden, A. (1989), Asia's Next Giant: South Korea and Late Industrialization, New York: Oxford University Press.

Armington, P.S. (1969), "A Theory of Demand for Products Distinguished by Place of Production", IMF Staff papers 16, Washington, D.C.

ASEAN Secretariat (1993a), AFTA Reader: Questions and Answers on the CEPT for AFTA: Volume 1, ASEAN Secretariat, Jakarta.

ASEAN Secretariat (1993b), AFTA Reader: Questions and Answers on the CEPT for AFTA: Volume II, ASEAN Secretariat, Jakarta.

ASEAN Secretariat (1995), AFTA Reader: New Time Frame: Acceleration of Tariff Reduction: Volume III, ASEAN Secretariat, Jakarta.

ASEAN Secretariat (1996), AFTA Reader: The Fifth ASEAN Summit: Volume IV, ASEAN Secretariat, Jakarta.

ASEAN Secretariat (July, 1997/1998), CEPT Product Lists, Fourth/Fifth Edition.

Balassa, B. (1965), "Trade Liberalization and Revealed Comparative Advantage", the Manchester School of Economics and Social Studies, vol.3, no 2 May, pp.99-124.

Center for International Economics (1998), Vietnam Tariff Schedule, February 1998, Canberra.

Centre for International Economics (1998, July), Vietnam's Trade Policies 1998, Canberra.

Corden, M. (1994), "What is the Competitiveness Problem", Economic Policy, Exchange Rates, and the International System, Oxford University Press and University of Chicago Press.

Dollar, D. (1998), “The Transformation of Vietnam's Economy: Sustaining Growth in the 21th Century," World Bark. Washington, D.C.

Dollar, D. (1996), "Economic Reform, Openness, and Vietnam's Entry into ASEAN," ASEAN Economic Bulletin, November 1996.

Flatters, F. (1998a), "Vietnam and AFTA: By Choice or Obligation?" in Neal Forster (eds), Vietnam's Integration with ASEAN: A Policy Reader, Vietnam. 
Flatters, F. (1998b), "ASEAN and the Economic Crisis: Lessons for Vietnam", UNDPFunded Research Report No. 7, VIE/95/015, Hanoi, Vietnam.

Fukase, E. and Martin, W. (1998), "Assessing the Effects of Lowering the Maximum Tariff Rates of Vietnam's Tariff Schedule", mimeo, World Bank, Washington, D.C.

Fukase, E. and Winters, L.A. (1999), "Possible Dynamic Benefits of ASEAN/AFTA Accession for the New Member Countries", mimeo, World Bank, Washington, D.C.

Gehlhar, M., Hertel, T. and Martin, W. (1994), "Economic Growth and the changing structure of trade and production in the Pacific Rim", American Journal of Agricultural Economics 76(December):1101-1110.

General Statistical Office (1997), Statistical Yearbook 1997, Vietnam.

Herrou-Aragon, A. (1999), "Protection and Export Incentives in Dominican Republic", mimeo, World Bank, Washington, D.C.

Hertel, T. (1997), Global Trade Analysis: Modeling and Applications, Cambridge University Press.

Hertel, T., and Huff, A.M. (1997), "Decomposing Welfare Changes in the GTAP Model", GTAP Technical Paper No.5.

Johnson, H. (1955), "Optimal trade intervention in the presence of domestic distortions," in Baldwin, R. E. ed. Trade, Growth and the Balance of Payments, Rand McNally, Chicago.

Le Bo Linh (1998), "Vietnam's Trade Policies in the New Period: Boosting Import-Export and the Issue of Protectionism", Vo Dai Luoc (eds.) Vietnam's policies on Trade and Investment and the Development of Some Key Industries, Institute of World Economy, Hanoi, Vietnam.

McDougall, R. (1993), "Two Small Extensions to SALTER", SMALL Extensions to SALTER Working paper No.12.

McCarty, A. (1998), "ASEAN and Foreign Direct Investment in Vietnam", in Neal Forster (eds), Vietnam's Integration with ASEAN: A Policy Reader, Vietnam.

McCarty, A. (1999), "Vietnam's Integration with ASEAN: Survey of Non-tariff Measures Affecting Trade", A report prepared for the office of the Government, UNDP-Funded Research Report No.8, VIE/95/015. 
Martin, W. (1996a), "Measuring welfare changes with distortions", in Francois, J. and Reinert, K. eds. Applied Methods for Trade Policy Analysis: A Handbook, Cambridge University Press, Cambridge, U.K.

Martin, W. and Warr, P. (1994), "Determinants of agriculture's relative decline:

Thailand", Agricultural Economics 11:219-35.

Martin, W. and Winters, L. A. (1996), The Uruguay Round and the Developing Countries, Cambridge University Press, Cambridge.

Ministry of Finance (1998), "Decision No. 590A/1998/QD/BTC of April 29, 1998 of the Minister of Finance Issuing the Index of Minimum Purchase Prices at Border Gates for Import Tax Calculation", Vietram.

Ministry of Trade (1998), "Circular No. 01/1998TM/XNK of February 14, 1998 Providing Guidance for the Implementation of Decision 11/1998/QD-TTg Governing the Management: Mechanism of Import-export Activities in 1998 and Decision 12/1998/QD-TTg Governing the Management of Rice Exports and Fertilizer Imports in 1998", Vietnam.

Panagariya, A. (1994), "East Asia and the New Regionalism in World Trade", World Economy, 17:817-39, Novernber 1994.

Puga, D. and Venables, A.J. (1997), "Preferential Trading Arrangement and Industrial Location", Journal of International Economics 43(3-4), pp.347-68.

Puga, D. and Venables, A.J. (June, 1998), "Agglomeration and Economic Development: Import Substitution vs. Trade Liberalization", Centre for Economic Performance, Discussion Paper No.377.

Pursell, G. (1999), "The Australian Experience with FDI and Local Content Programs in the Auto Industry", World Bank, Washington, D.C.

Sachs, J. D. and Warner, A. (1995), "Economic Reform and the Process of Global Integration", Brookings Papers on Economic Activity, No.1.

Salter, W.E.G. (1959), "Internal and External Balance: the Role of Price and Expenditure Effects", Economic Record 35(71):226-38.

Technical Group, Institute of Economics (Vietnam) - IDRC (Canada) (1999), "Textile and Garment Industry in Vietnam", Project on Trade Policy and Competitiveness, Hanoi.

Wade, R (1998), governing the Market, Princeton University Press. 
Winters, L. Alan (1996), "Lebanon's Euro-Mediterranean Agreement: Possible Dynamic Effects", World Bank, Washington, D.C.

World Bank (1993), The East Asia Miracle, Oxford University Press for the World Bank, Oxford.

World Bank, (1998a), World Development Indicators, Washington, DC.

World Bank (1998b), Vietnam: Rising to the Challenge, An Economic Report of the World Bank Consultative Group Meeting for Vietnam, December 7-8, 1998.

World Trade Organization (March, 1998), "Accession of Vietnam: Questions and Replies to the Memorandum on the Foreign Trade Regime", (Document $\mathrm{WT} / \mathrm{ACC} / \mathrm{VNM} / 2$ ).

WTO (1995), The Results of the Uruguay Round of Multilateral Trade Negotiations: The Legal Texts, World Trade Organization, Geneva.

(vnaftawp.doc) 
Annex 1. Revealed Comparative Advantage for ASEAN 10 (1990-1995 Average)

\begin{tabular}{|c|c|c|c|c|c|c|c|c|c|c|c|}
\hline SITC & Description & Brunei & Indonesia & Cambodia & $\begin{array}{l}\text { Lao } \\
\text { PDR }\end{array}$ & Malaysia & Myanmar & Philippines & Singapore & Thailand & Vietnam \\
\hline 0 & LIVE ANIMALS & 0.0 & 0.0 & 0.0 & 1.3 & 1.8 & 0.2 & 0.0 & 0.0 & 0.1 & 0.0 \\
\hline 1 & MEAT AND PREPARATIONS & 0.0 & 0.1 & 0.0 & 0.0 & 0.0 & 0.0 & 0.0 & 0.0 & 1.4 & 0.1 \\
\hline 2 & DAIRY PRODUCTS AND EGGS & 0.0 & 0.3 & 0.0 & 0.0 & 0.3 & 0.0 & 0.0 & 0.2 & 0.1 & 0.8 \\
\hline 3 & FISH AND PREPARATIONS & 0.0 & 3.4 & 1.6 & 0.1 & 0.7 & 9.5 & 3.7 & 0.5 & 8.7 & 11.3 \\
\hline \multirow[t]{2}{*}{4} & CEREALS AND PREPARATIONS & 0.0 & 0.1 & 0.6 & 0.1 & 0.2 & 3.3 & 0.1 & 0.2 & 3.3 & 6.6 \\
\hline & (Of which 42 RICE) & 0.0 & 0.3 & 0.0 & 0.0 & 0.0 & 27.6 & 0.2 & 0.1 & 28.7 & 69.7 \\
\hline 5 & FRUIT AND VEGETABLES & 0.0 & 0.6 & 0.1 & 0.2 & 0.3 & 8.3 & 4.5 & 0.1 & 3.1 & 1.5 \\
\hline 6 & SUGAR AND PREPS HONEY & 0.0 & 0.5 & 0.0 & 0.0 & 0.5 & 0.5 & 3.3 & 0.1 & 7.0 & 0.8 \\
\hline \multirow[t]{2}{*}{7} & COFFEE TEA COCOA SPICES & 0.0 & 4.8 & 1.2 & 7.0 & 1.3 & 1.7 & 0.4 & 0.6 & 0.8 & 9.2 \\
\hline & (Of which 71 COFFEE) & 0.0 & 5.2 & 0.0 & 14.9 & 0.0 & 0.1 & 0.3 & 0.1 & 1.2 & 16.9 \\
\hline 8 & ANLMAL FEEDING STUFF & 0.0 & 1.0 & 0.0 & 0.0 & 0.6 & 1.4 & 1.3 & 0.2 & 1.6 & 0.1 \\
\hline 11 & BEVERAGES & 0.0 & 0.0 & 0.0 & 0.0 & 0.1 & 0.0 & 0.1 & 0.3 & 0.1 & 0.1 \\
\hline 12 & TOBACCO AND MFRS & 0.0 & 0.8 & 0.0 & 0.0 & 0.1 & 0.1 & 1.0 & 0.4 & 0.8 & 0.1 \\
\hline 21 & HIDES,SKINS,FURS UNDRSSD & 0.0 & 0.1 & 3.3 & 4.1 & 0.1 & 1.9 & 0.0 & 0.0 & 0.1 & 2.7 \\
\hline 22 & OIL SEEDS,NUTS,KERNELS & 0.0 & 0.1 & 7.6 & 0.5 & 0.1 & 16.7 & 0.5 & 0.1 & 0.1 & 7.0 \\
\hline 23 & RUBBER CRUDE,SYNTHETIC & 0.0 & 12.1. & 64.5 & 0.0 & 10.8 & 7.5 & 0.5 & 1.8 & 14.2 & 3.4 \\
\hline 24 & WOOD LUMBER AND CORK & 0.0 & 2.4 & 48.0 & 53.9 & 9.2 & 45.4 & 0.7 & 0.3 & 0.2 & 3.6 \\
\hline 25 & PULP AND WASTE PAPER & 0.0 & 0.6 & 0.0 & 0.0 & 0.0 & 0.0 & 0.5 & 0.2 & 0.1 & 0.0 \\
\hline \multirow[t]{2}{*}{26} & TEXTILE FIBRES & 0.0 & 0.2 & 1.9 & 0.1 & 0.3 & 0.3 & 0.4 & 0.1 & 0.7 & 0.7 \\
\hline & (OF WHICH 261 SILK) & 0.0 & 0.0 & 0.0 & 0.0 & 0.0 & 0.0 & 0.0 & 0.2 & 0.9 & 9.2 \\
\hline 27 & CRUDE FERTLZR,MINRLS NES & 0.0 & 0.3 & 0.0 & 0.3 & 0.3 & 0.1 & 0.4 & 0.2 & 1.2 & 0.3 \\
\hline 28 & METALLIFEROUS ORES,SCRAP & 0.1 & 2.8 & 2.8 & 3.9 & 0.4 & 1.7 & 3.8 & 0.4 & 0.1 & 1.0 \\
\hline 29 & CRUDE ANIMAL, VEG MAT NES & 0.0 & 0.5 & 2.3 & 3.4 & 0.3 & 2.4 & 1.2 & 0.5 & 1.4 & 3.1 \\
\hline 32 & COAL,COKE,BRIQUETTES & 0.0 & 3.1 & 0.0 & 0.0 & 0.0 & 0.0 & 0.0 & 0.0 & 0.0 & 4.1 \\
\hline 33 & PETROLEUM AND PRODUCTS & 6.4 & 2.6 & 0.0 & 0.0 & 1.1 & 0.1 & 0.1 & 1.9 & 0.1 & 2.9 \\
\hline 34 & GAS NATURAL AND MANUFCTD & 40.3 & 14.4 & 0.0 & 0.0 & 3.0 & 0.0 & 0.7 & 0.2 & 0.0 & 0.0 \\
\hline 41 & ANIMAL OILS AND FATS & 0.0 & 0.6 & 0.0 & 0.0 & 1.2 & 0.0 & 0.3 & 0.2 & 0.0 & 0.0 \\
\hline 42 & FLXED VEGETABLE OIL,FAT & 0.0 & 6.2 & 0.0 & 0.0 & 15.2 & 0.0 & 11.6 & 1.7 & 0.1 & 0.8 \\
\hline 43 & PROCESD ANML VEG OIL,ETC & 0.0 & 2.7 & 0.0 & 0.0 & 16.2 & 0.0 & 3.6 & 1.5 & 0.7 & 0.0 \\
\hline 51 & CHEM ELEMENTS,COMPOUNDS & 0.0 & 0.3 & 0.0 & 0.1 & 0.2 & 0.1 & 0.2 & 0.8 & 0.1 & 0.0 \\
\hline 52 & COAL,PETROLEUM ETC CHEMS & 0.0 & 0.0 & 0.0 & 0.0 & 0.6 & 0.0 & 0.0 & 4.0 & 0.1 & 0.0 \\
\hline 53 & DYES,TANNNG,COLOUR PROD & 0.0 & 0.2 & 0.0 & 0.0 & 0.2 & 0.1 & 0.0 & 0.7 & 0.3 & 0.0 \\
\hline 54 & MEDICINAL ETC PRODUCTS & 0.0 & 0.1 & 0.0 & 0.0 & 0.1 & 0.0 & 0.1 & 0.3 & 0.1 & 0.0 \\
\hline 55 & PERFUME,CLEANING ETC PRD & 0.0 & 0.4 & 0.0 & 0.0 & 0.4 & 0.0 & 0.2 & 0.5 & 0.3 & 0.3 \\
\hline 56 & FERTILIZERS MANUFACTURED & 0.0 & 1.1 & 0.0 & 0.0 & 0.4 & 0.0 & 1.5 & 0.1 & 0.0 & 0.1 \\
\hline 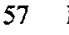 & EXPLOSIVES,PYROTECH PROD & 0.0 & 0.1 & 0.0 & 0.0 & 0.2 & 0.0 & 1.5 & 0.1 & 0.1 & 0.0 \\
\hline $58 \quad 1$ & PLASTIC MATERIALS ETC & 0.0 & 0.1 & 0.0 & 0.0 & 0.2 & 0.0 & 0.1 & 0.7 & 0.3 & 0.1 \\
\hline 611 & LEATHER,DRESSED FUR,ETC & 0.0 & 0.6 & 0.0 & 0.9 & 0.1 & 0.3 & 0.3 & 0.1 & 2.0 & 0.4 \\
\hline 621 & RUBBER MANUFACTURES NES & 0.0 & 0.4 & 0.2 & 0.0 & 0.8 & 0.0 & 0.2 & 0.3 & 0.9 & 1.3 \\
\hline 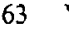 & WOOD,CORK MANUFACTRS & 0.0 & 18.5 & 0.0 & 3.6 & 3.6 & 0.9 & 2.0 & 0.6 & 1.1 & 1.1 \\
\hline 64 & PAPER,PAPERBOARD AND MFR & 0.0 & 0.5 & 0.0 & 0.0 & 0.2 & 0.0 & 0.1 & 0.3 & 0.2 & 0.1 \\
\hline 65 & TEXTILE YARN,FABRIC ETC & 0.0 & 1.6 & 0.1 & 0.1 & 0.4 & 0.0 & 0.4 & 0.2 & 1.2 & 1.8 \\
\hline 66 & NONMETAL MINERAL MFS NES & 0.1 & 0.4 & 0.0 & 0.0 & 0.4 & 3.4 & 0.4 & 0.2 & 1.9 & 0.4 \\
\hline 67 & IRON AND STEEL & 0.0 & 0.2 & 0.0 & 0.3 & 0.2 & 0.1 & 0.1 & 0.2 & 0.2 & 0.7 \\
\hline 687 & NON-FERROUS METALS & 0.0 & 0.6 & 0.0 & 0.0 & 0.4 & 0.2 & 1.1 & 0.3 & 0.1 & 0.4 \\
\hline 69 & METAL MANUFACTURES NES & 0.0 & 0.3 & 0.0 & 0.0 & 0.4 & 0.0 & 0.3 & 0.6 & 0.6 & 0.3 \\
\hline 71 & MACHINERY,NON-ELECTRIC & 0.0 & 0.0 & 0.0 & 0.0 & 0.7 & 0.1 & 0.5 & 2.2 & 1.0 & 0.1 \\
\hline 721 & ELECTRICAL MACHINERY & 0.0 & 0.2 & 0.0 & 0.0 & 2.9 & 0.0 & 2.5 & 2.4 & 1.3 & 0.1 \\
\hline 73 & TRANSPORT EQUIPMENT & 0.0 & 0.1 & 0.0 & 0.0 & 0.1 & 0.0 & 0.1 & 0.2 & 0.1 & 0.1 \\
\hline 81 & PLUMBG,HEATNG,LGHTNG EQU & 0.0 & 0.2 & 0.0 & 0.0 & 0.3 & 0.0 & 0.9 & 0.2 & 0.8 & 0.1 \\
\hline 821 & FURNITURE & 0.0 & 2.0 & 0.1 & 0.2 & 0.9 & 0.1 & 2.2 & 0.4 & 1.8 & 0.9 \\
\hline 83 & TRAVEL GOODS,HANDBAGS & 0.0 & 0.5 & 0.5 & 0.1 & 0.2 & 0.0 & 2.0 & 0.1 & 2.8 & 3.5 \\
\hline 84 & CLOTHING & 0.4 & 2.1 & 4.8 & 8.1 & 1.4 & 1.5 & 4.4 & 0.5 & 2.2 & 3.1 \\
\hline 85 & FOOTWEAR & 0.0 & 4.6 & 0.1 & 0.1 & 0.3 & 0.1 & 1.5 & 0.1 & 2.9 & 4.0 \\
\hline 861 & INSTRMNTS, WATCHES,CLOCKS & 0.7 & 0.1 & 0.0 & 0.0 & 0.6 & 0.0 & 1.0 & 0.8 & 0.7 & 0.1 \\
\hline 891 & MISC MANUFCTRD GOODS NES & 2.0 & 0.4 & 0.1 & 0.1 & 1.4 & 0.1 & 1.0 & 1.2 & 1.9 & 0.3 \\
\hline 935 & SPECIAL TRANSACTIONS & 0.4 & 0.1 & 2.6 & 0.3 & 0.6 & 0.2 & 0.6 & 1.0 & 0.5 & 0.2 \\
\hline 942 & ZOO ANIMALS,PETS & 0.0 & 3.5 & 0.0 & 0.0 & 0.6 & 2.9 & 3.5 & 0.5 & 1.2 & 1.9 \\
\hline 95 & WAR FIREARMS,AMMUNITION & 0.4 & 0.1 & 0.0 & 0.0 & 0.0 & 0.0 & 0.1 & 0.2 & 0.0 & 0.0 \\
\hline
\end{tabular}

Source: UN Comtrade System 


\begin{tabular}{|c|c|c|c|c|c|c|c|c|c|c|c|c|c|c|c|c|}
\hline \multicolumn{17}{|c|}{ Annex 2. MFN Tariff Rates for ASEAN Countries } \\
\hline \multirow{3}{*}{ Section } & \multirow{3}{*}{ HS } & \multirow{3}{*}{ Description } & \multicolumn{2}{|c|}{ Cambodia } & \multicolumn{2}{|c|}{ Indonesia } & \multicolumn{2}{|c|}{ Malaysia } & \multicolumn{2}{|c|}{ Philippines } & \multicolumn{2}{|c|}{ Lan PDR } & \multicolumn{2}{|c|}{ Thailand } & \multicolumn{2}{|c|}{ Vietnam } \\
\hline & & & Simple & Weighted & Simple & Weighted & Simple & Weighted & Simple & Weighted & Simple & weighted & Simple & Weighted & Simple & Weighted \\
\hline & & & & & & & & & & & & & & & Average $\%$ ) & Average(\%) \\
\hline 1 & $1-5$ & Animals \& animal products & 10.2 & 6.7 & 15.9 & 10.8 & 8.9 & 1.7 & 23.6 & 14.2 & 13.9 & 7.1 & 39.4 & 34.2 & 11.5 & 13.7 \\
\hline 2 & $6-14$ & Vegetable products & 14.3 & 9.0 & 12.2 & 3.6 & 2.3 & 3.1 & 22.1 & 37.6 & 22.7 & 13.0 & 30.4 & 13.3 & 17.2 & 11.5 \\
\hline 3 & 15 & Animal \& Vegetable oils & 6.1 & 5.6 & 8.3 & 3.8 & 1.6 & 0.7 & 20.4 & 17.7 & 10.7 & 10.1 & 17.4 & 16.1 & 12.1 & 19.5 \\
\hline 4 & $16-24$ & Processed foods, drinks \& tobacco & 28.5 & 28.3 & 26.6 & 5.6 & 6.4 & 3.0 & 26.7 & 21.1 & 24.5 & 30.7 & 38.2 & 23.5 & 34.0 & 43.6 \\
\hline 5 & $25-27$ & Oil and minerals products & 10.4 & 21.5 & 4.6 & 3.1 & 1.9 & 1.1 & 4.7 & 8.0 & 5.1 & 5.0 & 10.8 & 5.7 & 4.3 & 41.2 \\
\hline 6 & $28-38$ & Chemical products & 10.8 & 6.7 & 6.4 & 5.3 & 1.1 & 1.2 & 6.4 & 7.5 & 8.9 & 10.5 & 15.8 & 14.7 & 5.2 & 5.1 \\
\hline 7 & $39-40$ & Plastic \& rubber products & 11.7 & 10.6 & 15.6 & 14.9 & 12.4 & 9.7 & 13.5 & 13.9 & 11.7 & 12.1 & 31.1 & 28.0 & 9.5 & 8.5 \\
\hline 8 & $41-43$ & Skins \& furs and their products & 22.5 & 27.5 & 10.7 & 0.9 & 4.0 & 2.5 & 18.4 & 19.8 & 12.2 & 13.7 & 27.4 & 8.3 & 11.6 & 6.2 \\
\hline 9 & $44-46$ & Wood \& wood products & 28.8 & 28.4 & 10.6 & 5.3 & 16.1 & 18.9 & 20.9 & 15.0 & 27.6 & 31.0 & 21.6 & 9.2 & 16.1 & 9.7 \\
\hline 10 & $47-49$ & Pulp of wood \& paper & 5.4 & 5.6 & 9.3 & 5.8 & 8.9 & 6.8 & 15.5 & 14.3 & 7.4 & 8.8 & 23.4 & 14.6 & 16.2 & 19.0 \\
\hline 11.1 & $50-60$ & Textiles & 15.1 & 13.2 & 17.4 & 9.6 & 10.5 & 10.0 & 16.2 & 15.4 & 9.2 & 9.5 & 28.1 & 20.0 & 23.3 & 27.8 \\
\hline 11.2 & $61-63$ & Apparel & 20.7 & 12.5 & 27.8 & 28.2 & 14.2 & 11.9 & 27.4 & 27.1 & 10.7 & 10.3 & 45.0 & 42.3 & 48.9 & 46.3 \\
\hline 12 & $64-67$ & Shoes, hats, umbrellas, etc. & 19.8 & 10.3 & 21.9 & 15.7 & 13.1 & 15.7 & 29.5 & 23.7 & 12.1 & 10.1 & 43.6 & 37.3 & 40.5 & 21.9 \\
\hline 13 & $68-70$ & Stone, ceramic \& glass products & 11.7 & 7.6 & 10.2 & 7.0 & 10.0 & 7.2 & 20.1 & 19.2 & 5.9 & 5.2 & 39.9 & 29.5 & 22.9 & 28.6 \\
\hline 14 & 71 & Jewelry \& precious metal products & 22.2 & 0.0 & 12.0 & 8.4 & 3.5 & 0.3 & 8.0 & 3.6 & 5.0 & 5.0 & 17.3 & 2.0 & 16.7 & 6.3 \\
\hline 15 & $72-83$ & Base metals \& their products & 12.6 & 6.7 & 9.8 & 6.3 & 5.0 & 5.6 & 14.4 & 12.8 & 5.9 & 5.9 & 15.7 & 9.6 & 9.2 & 9.2 \\
\hline 16 & $84-85$ & Electrical \& mechanical equipment & 13.8 & 11.8 & 5.5 & 4.9 & 4.0 & 2.1 & 8.5 & 5.7 & 6.8 & 7.7 & 12.6 & 11.7 & 6.4 & 9.1 \\
\hline 17 & $86-89$ & Transport equipment & 22.8 & 21.6 & 25.6 & 26.0 & 11.3 & 9.5 & 13.5 & 17.3 & 17.9 & 26.9 & 18.9 & 19.6 & 10.3 & 27.8 \\
\hline 18 & $90-92$ & Photographic, optical, precision instruments & 8.2 & 4.1 & 9.3 & 7.7 & 2.7 & 2.2 & 10.3 & 7.3 & 6.2 & 6.0 & 15.5 & 14.0 & 8.8 & 4.0 \\
\hline 19 & 93 & Arms \& munitions & 18.8 & 12.3 & 12.6 & 11.1 & n.a. & n.a. & 28.0 & 25.9 & 30.0 & 30.0 & 30.0 & 30.3 & 11.0 & 14.9 \\
\hline 20 & 94-96 & Miscellaneous articles & 15.0 & 15.3 & 20.1 & 19.1 & 10.3 & 10.0 & 21.8 & 23.0 & 13.4 & 13.2 & 33.9 & 34.1 & 27.7 & 28.9 \\
\hline 21 & $97-98$ & Objets d'art & 0.8 & 0.0 & 14.1 & 8.9 & 4.4 & 2.2 & 30.0 & 30.0 & 5.0 & 5.0 & 17.1 & 15.3 & 6.5 & 5.5 \\
\hline & & Total & 13.9 & 14.9 & 12.3 & 7.8 & 6.2 & 3.6 & 15.2 & 10.9 & 9.6 & 14.7 & 23.3 & 13.7 & 15.6 & 19.0 \\
\hline
\end{tabular}

Sources: ASEAN Secretariat, CEPT Product Lists 1997/1998; Center for International Economics (1998); 1995 COMTRADE System; Cambodia Customs House (1996)

Note: Singapore's tariff rates are close to zero although some specific tariffs are collected from such items as automobiles and petroleum oils. 
Annex 3. The Structure of Vietnam's Liberalization Schedules

\begin{tabular}{|c|c|c|c|c|c|c|c|c|c|c|c|c|}
\hline & \multicolumn{3}{|c|}{$\begin{array}{l}\text { Inclusion List } \\
\text { (IL) }\end{array}$} & \multicolumn{3}{|c|}{$\begin{array}{l}\text { Temporary Exclusion List } \\
\text { (TEL) }\end{array}$} & \multicolumn{3}{|c|}{$\begin{array}{l}\text { Sensitive List } \\
\text { (SL) }\end{array}$} & \multicolumn{3}{|c|}{$\begin{array}{l}\text { General Exception List } \\
\text { (GEL) }\end{array}$} \\
\hline & $\underline{\text { Imports }}$ & $\frac{\text { Exports }}{(\$ 1,000)}$ & $\frac{\text { W. Tariff }}{\text { Rate (\%) }}$ & $\begin{array}{l}\text { Imports } \\
(\$ 1,000)\end{array}$ & $\frac{\text { Exports }}{(\$ 1,000)}$ & $\begin{array}{l}\text { W. Tariff } \\
\text { Rate }(\%)\end{array}$ & $\frac{\text { Imports }}{(\$ 1,000)}$ & $\frac{\text { Exports }}{(\$ 1,000)}$ & $\begin{array}{l}\text { W. Tariff } \\
\text { Rate }(\%)\end{array}$ & $\frac{\text { Imports }}{(\$ 1,000)}$ & $\begin{array}{l}\text { Exports } \\
(\$ 1,000)\end{array}$ & $\begin{array}{l}\text { W. Tariff } \\
\text { Rate }(\%)\end{array}$ \\
\hline AGR & 28390 & 256932 & 5.3 & 3346 & 8317 & 10.5 & 813 & 7493 & 3.9 & 479 & 3272 & 24.8 \\
\hline BMF & 129299 & 27027 & 6.7 & 1613592 & 4141 & 20.8 & 0 & 0 & na & 0 & 0 & 10.0 \\
\hline BTP & 0 & 0 & na & $5: 35$ & 119 & 60.0 & 0 & 0 & na & 229658 & 0 & 50.0 \\
\hline CLO & 5281 & 11482 & 48.5 & 460 & 207 & 33.0 & 0 & 0 & na & 0 & 0 & na \\
\hline COG & 16933 & 211968 & 11.4 & 12588 & 815 & 14.2 & 0 & 0 & na & 53 & 0 & 10.0 \\
\hline CRP & 165650 & 1440 & 4.4 & $40: 2818$ & 15688 & 6.4 & 0 & 0 & na & 418 & 33 & 10.7 \\
\hline LMF & 7163 & 1193 & 9.2 & 20911 & 20651 & 22.3 & 0 & 0 & na & 35 & 103 & 4.3 \\
\hline MCE & 284620 & 48377 & 6.0 & 209065 & 8003 & 24.3 & 0 & 0 & na & 78494 & 992 & 6.9 \\
\hline PAG & 30313 & 37919 & 19.0 & $13 ! 522$ & 275823 & 26.3 & 463 & 0 & 34.4 & 14561 & 0 & 23.2 \\
\hline PCP & 18002 & 0 & 1.8 & 6402 & 5 & 1.1 & 0 & 0 & na & 641778 & 3296 & 46.1 \\
\hline TEX & 32910 & 1287 & 6.4 & 88052 & 3831 & 27.2 & 0 & 0 & na & 0 & 0 & na \\
\hline \multirow[t]{2}{*}{ TRP } & 25762 & 2203 & 25.8 & 28797 & 1098 & 30.1 & 0 & 0 & na & 126730 & 67 & 33.8 \\
\hline & 744322 & 599828 & 7.3 & 1085687 & 338698 & 17.5 & 1275.969 & 7493 & 15.0 & 1092205 & 7763 & 42.3 \\
\hline Share (\%) & 25.5 & 62.9 & & 37.1 & 35.5 & & 0.04 & 0.8 & & 37.4 & 0.8 & \\
\hline
\end{tabular}

Sources: ASEAN Secretariat, CEPT Products Lists (1997/1998); Center for International Economics (1998); 1996 Trains Database, 
REGIONS

1. Indonesia (IDN)

2. Malaysia (MYS)

3. The Philippines (PHL)

4. Singapore (SGP)

5. Thailand (THA)

6. Vietnam (VNM)

7. Japan(JPN)

8. EU15 (EU15)

9. United States (USA)

10. Hong-Kong, Korea (NIEs)

11. China (CHN)

12. ROW (ROW)

SECTORS

1. AGR(Agriculture and forestry)

1. paddy rice

2. wheat

3. cereal grains

4. vegetables, fruits, nuts

5. oil seeds

6. sugar cane

7. plant based fibers

8. crops n.e.c.

9. bovine cattle, sheep, goat, etc

10. animal products

12. wool, silk-worm, cocoons

13. forestry

14. fishing

2. PAG(Processed agriculture)

19. bovine, cattle etc meat

20. meat products

21. vegetable oils \& fats

22 . daily products

23. processed rice

24. sugar

25. food products n.e.c.

3. BTP (Beverage and tobacco products)

26 . beverages $\&$ tobacco products

4. COG (Coal, oil, gas)

15. coal

16. oil

17. gas
18. minerals, n.e.c.

\section{PCP (Petroleum and coal products)}

32. petroleum \& coal products

6. TEX (Textiles)

27. textiles

7. CLO(Apparel)

28. apparel

8. LMF(Light manufacturing)

29. leather products

30 . wood products

42. manufactures n.e.c.

9. BMF(Basic manufacturing)

31. paper products, publishing

34. mineral products

35. ferrous metals

36. metal n.e.c.

37. metal products

10. CRP (Chemical, rubber, plastic products)

33. chemical, rubber, plastic products

11. TRP (Transport Equipment)

38. motor vehicles \& parts

39. transport equipment n.e.c.

12. MCE (Electronics and Machinery)

40. electronic equipment

41. machinery \& equipment

13. OTH (Others)

43. electricity

44. gas manufacture, distribution

45. water

46. construction

47. trade, transport

48. financial business, recreational services

49. pubic administration and defense, education, health services

50. dwellings 
Annex 5-A. Changes in Vietnam's Imports by Source

\begin{tabular}{|c|cccccccccc|}
\hline \multicolumn{2}{|c}{} & IDN & MYS & PHL & SGP & THA & NIES & EU15 & USA & CHI \\
\hline \multicolumn{7}{|c}{} & \multicolumn{7}{c|}{ SCENARIO 1 (AFTA 1) } \\
\hline AGR & $10(13)$ & $1(2)$ & $0.3(170)$ & $7(23)$ & $25(3)$ & $2(1)$ & $8(0.8)$ & $15(1)$ & $19(1)$ & $1(1)$ \\
PAG & $6(102)$ & $114(55)$ & $8(65)$ & $53(36)$ & $105(77)$ & $12(-23)$ & $73(-23)$ & $8(-23)$ & $12(-23)$ & $6(-23)$ \\
BTP & $7(97)$ & $1(-4)$ & $2(-4)$ & $325(-0.2)$ & $5(365)$ & $30(-4)$ & $15(-4)$ & $1(-3)$ & $115(-4)$ & $0.05(0)$ \\
COG & $3(1)$ & $1(12)$ & $1(67)$ & $7(-3)$ & $32(65)$ & $0.3(-4)$ & $21(-5)$ & $0.5(-4)$ & $3(-5)$ & $0.6(-5)$ \\
PCP & 0 & $10(3)$ & $8(0)$ & $395(-0.3)$ & $19(0.2)$ & 0 & $4(0)$ & $0.8(0)$ & $10(0)$ & $29(0)$ \\
TEX & $53(106)$ & $57(18)$ & $2(125)$ & $79(156)$ & $73(153)$ & $343(-9)$ & $38(-9)$ & $6(-9)$ & $78(-9)$ & $107(-9)$ \\
CLO & $30(944)$ & $6(468)$ & $1(1017)$ & $14(1074)$ & $8(921)$ & $3(-55)$ & $0.4(-54)$ & $0.1(-54)$ & $7(-55)$ & $3(-55)$ \\
LMF & $9(-5)$ & $14(36)$ & $1(304)$ & $80(120)$ & $28(134)$ & $79(-22)$ & $15(-22)$ & $5(-22)$ & $17(-22)$ & $17(-22)$ \\
BMF & $74(60)$ & $49(60)$ & $1(14)$ & $191(45)$ & $115(52)$ & $186(-15)$ & $72(-15)$ & $19(-15)$ & $161(-15)$ & $97(-15)$ \\
CRP & $192(2)$ & $49(14)$ & $99(2)$ & $262(19)$ & $93(17)$ & $184(-7)$ & $200(-7)$ & $51(-7)$ & $156(-7)$ & $107(-7)$ \\
TRP & $38(-12)$ & $4(27)$ & $17(968)$ & $70(105)$ & $174(56)$ & $116(-15)$ & $85(-15)$ & $90(-15)$ & $19(-15)$ & $265(-15)$ \\
MCE & $6(26)$ & $113(99)$ & $3(2)$ & $578(35)$ & $110(89)$ & $254(-16)$ & $362(-16)$ & $89(-16)$ & $173(-16)$ & $322(-16)$ \\
OTH & $3(0.3)$ & $3(0.3)$ & $4(0.2)$ & $2(0)$ & $4(0)$ & $133(0.3)$ & $13(0.2)$ & $3(0.3)$ & $4(0.2)$ & $2(0.5)$ \\
\hline Total & $431(26)$ & $420(50)$ & $147(19)$ & $2061(24)$ & $791(60)$ & $1343(-12)$ & $906(-13)$ & $287(-13)$ & $774(-12)$ & $959(-14)$ \\
\hline
\end{tabular}

\begin{tabular}{|l|cccccccccc|}
\hline \multicolumn{10}{|c|}{ SCENARIO 2 (AFTA 2) } \\
\hline AGR & $10(16)$ & $1(7)$ & $0.3(180)$ & $7(26)$ & $26(7)$ & $2(4)$ & $8(4)$ & $16(4)$ & $20(4)$ & $1(4)$ \\
PAG & $6(108)$ & $117(60)$ & $9(70)$ & $55(41)$ & $108(82)$ & $13(-21)$ & $75(-21)$ & $8(-21)$ & $12(-21)$ & $6(-21)$ \\
BTP & $7(99)$ & $0.5(-2)$ & $2(-3)$ & $328(1)$ & $5(370)$ & $30(-3)$ & $15(-3)$ & $1(-3)$ & $116(-3)$ & $0.1(0)$ \\
COG & $3(1)$ & $0.6(12)$ & $1(67)$ & $7(-3)$ & $32(65)$ & $0.3(-4)$ & $21(-4)$ & $0.5(-4)$ & $3(-4)$ & $0.6(-5)$ \\
PCP & 0.0 & $10(3)$ & $8(0.1)$ & $395(-0.1)$ & $19(0.4)$ & 0.0 & $4(0)$ & $0.8(0)$ & $10(0.1)$ & $29(0.1)$ \\
TEX & $52(102)$ & $56(16)$ & $2(121)$ & $77(151)$ & $71(148)$ & $336(-10)$ & $38(-10)$ & $6(-10)$ & $76(-10)$ & $105(-10)$ \\
CLO & $30(945)$ & $6(468)$ & $1(1017)$ & $14(1075)$ & $8(921)$ & $3(-55)$ & $0.4(-54)$ & $0.1(-54)$ & $7(-55)$ & $3(-55)$ \\
LMF & $9(-4)$ & $15(37)$ & $1(309)$ & $80(122)$ & $29(136)$ & $80(-21)$ & $15(-21)$ & $5(-21)$ & $17(-21)$ & $18(-21)$ \\
BMF & $75(61)$ & $49(61)$ & $1(14)$ & $192(46)$ & $116(53)$ & $188(-15)$ & $73(-15)$ & $19(-15)$ & $162(-15)$ & $98(-15)$ \\
CRP & $193(2)$ & $48(15)$ & $99(2)$ & $263(19)$ & $93(17)$ & $184(-7)$ & $200(-7)$ & $51(-7)$ & $157(-7)$ & $107(-7)$ \\
TRP & $38(-12)$ & $4(27)$ & $18(978)$ & $70(106)$ & $175(57)$ & $117(-15)$ & $85(-15)$ & $90(-15)$ & $19(-15)$ & $267(-15)$ \\
MCE & $6(27)$ & $113(99)$ & $3(3)$ & $579(35)$ & $110(89)$ & $254(-15)$ & $363(-15)$ & $88(-15)$ & $174(-15)$ & $323(-15)$ \\
OTH & $4(1)$ & $3(1)$ & $4(2)$ & $2(1)$ & $4(1)$ & $134(1)$ & $13(1)$ & $3(1)$ & $4(1)$ & $2(1)$ \\
\hline Total & $432(26)$ & $423(51)$ & $148(20)$ & $2069(25)$ & $795(61)$ & $1341(-12)$ & $910(-13)$ & $289(-13)$ & $777(-12)$ & $960(-14)$ \\
\hline
\end{tabular}

\begin{tabular}{|c|cccccccccc|}
\hline \multicolumn{10}{|c|}{ SCENARIO 3 (AFTA 3) } \\
\hline AGR & $9(13)$ & $1(7)$ & $0.3(200)$ & $8(29)$ & $26(5)$ & $2(3)$ & $8(2)$ & $16(2)$ & $19(2)$ & $1(-3)$ \\
PAG & $7(130)$ & $111(52)$ & $20(294)$ & $58(48)$ & $104(75)$ & $12(-25)$ & $71(-26)$ & $7(-26)$ & $11(-26)$ & $6(-26)$ \\
BTP & $8(130)$ & $1(92)$ & $4(108)$ & $662(103)$ & $3(145)$ & $6(-80)$ & $3(-80)$ & $0.2(-79)$ & $24(-80)$ & 0 \\
COG & $3(-1)$ & $1(15)$ & $1(59)$ & $9(31)$ & $32(64)$ & $0.2(-23)$ & $21(-6)$ & $0.5(0)$ & $3(-6)$ & $0.6(-5)$ \\
PCP & 0 & $5(-47)$ & $10(22)$ & $441(12)$ & $22(16)$ & 0 & $1(-70)$ & $0.3(-63)$ & $3(-70)$ & $9(-69)$ \\
TEX & $52(102 ?)$ & $56(17)$ & $2(124)$ & $76(145)$ & $72(151)$ & $340(-10)$ & $38(-10)$ & $6(-9)$ & $77(-10)$ & $106(-10)$ \\
CLO & $30(935)$ & $6(456)$ & $1(1067)$ & $13(1055)$ & $8(940)$ & $3(-54)$ & $0.4(-47)$ & $0.1(-58)$ & $7(-54)$ & $3(-54)$ \\
LMF & $9(-10)$ & $14(29)$ & $1(291)$ & $91(153)$ & $27(126)$ & $77(-24)$ & $14(-25)$ & $5(-24)$ & $16(-24)$ & $17(-24)$ \\
BMF & $72(54)$ & $47(53)$ & $1(14)$ & $183(39)$ & $113(49)$ & $182(-17)$ & $71(-17)$ & $18(-17)$ & $157(-17)$ & $96(-17)$ \\
CRP & $190(1)$ & $48(14)$ & $100(3)$ & $257(16)$ & $93(17)$ & $184(-7)$ & $199(-7)$ & $51(-7)$ & $156(-7)$ & $107(-7)$ \\
TRP & $190(339)$ & $6(103)$ & $6(264)$ & $76(123)$ & $517(364)$ & $38(-72)$ & $28(-72)$ & $29(-72)$ & $6(-72)$ & $87(-72)$ \\
MCE & $6(29)$ & $113(100)$ & $3(3)$ & $585(36)$ & $110(89)$ & $252(-16)$ & $358(-16)$ & $87(-16)$ & $172(-16)$ & $320(-16)$ \\
OTH & $3(-3)$ & $3(-4)$ & $4(-1)$ & $2(-1)$ & $4(-2)$ & $132(-1)$ & $13(-1)$ & $3(0.3)$ & $4(-1)$ & $2(-1)$ \\
\hline Total & $579(69)$ & $412(47)$ & $152(23)$ & $2461(48)$ & $1130(129)$ & $1226(-19)$ & $825(-21)$ & $224(-32)$ & $656(-25)$ & $754(-32)$ \\
\hline
\end{tabular}

\begin{tabular}{|c|cccccccccc|}
\hline \multicolumn{10}{|c|}{ SCENARIO 4 (UNILATERAL) } \\
\hline AGR & $9(5)$ & $1(-3)$ & $0.3(200)$ & $7(19)$ & $24(-3)$ & $2(-3)$ & $8(6)$ & $26(70)$ & $36(87)$ & $1(6)$ \\
PAG & $6(110)$ & $101(38)$ & $18(257)$ & $53(35)$ & $95(59)$ & $29(84)$ & $96(0.1)$ & $14(47)$ & $15(2)$ & $7(-10)$ \\
BTP & $6(63)$ & $1(35)$ & $3(49)$ & $469(44)$ & $2(70)$ & $46(48)$ & $24(51)$ & $1(47)$ & $177(48)$ & $0.1(100)$ \\
COG & $3(-1)$ & $0.6(15)$ & $1(59)$ & $9(30)$ & $32(63)$ & $0.3(15)$ & $21(-6)$ & $0.5(0)$ & $3(-3)$ & $0.6(-5)$ \\
PCP & 0 & $5(-51)$ & $9(13)$ & $409(3)$ & $20(7)$ & 0 & $2(-33)$ & $0.8(-1)$ & $4(-61)$ & $31(8)$ \\
TEX & $33(27)$ & $35(-27)$ & $1(45)$ & $48(54)$ & $45(58)$ & $580(55)$ & $73(73)$ & $5(-30)$ & $124(46)$ & $211(80)$ \\
CLO & $10(232)$ & $2(82)$ & $0.2(233)$ & $4(271)$ & $3(233)$ & $25(264)$ & $3(281)$ & $1(317)$ & $53(241)$ & $26(245)$ \\
LMF & $6(-33)$ & $10(-5)$ & $0.7(204)$ & $67(86)$ & $20(67)$ & $100(-1)$ & $29(54)$ & $8(36)$ & $35(64)$ & $20(-9)$ \\
BMF & $54(17)$ & $35(16)$ & $0.7(-21)$ & $138(5)$ & $86(13)$ & $248(13)$ & $90(6)$ & $23(5)$ & $224(18)$ & $110(-5)$ \\
CRP & $176(-7)$ & $44(5)$ & $92(-5)$ & $239(8)$ & $86(8)$ & $214(8)$ & $218(2)$ & $52(-4)$ & $166(-1)$ & $112(-3)$ \\
TRP & $78(79)$ & $3(-18)$ & $2(48)$ & $31(-9)$ & $211(89)$ & $150(9)$ & $21(-79)$ & $97(-9)$ & $13(-44)$ & $381(22)$ \\
MCE & $5(10)$ & $97(71)$ & $3(-11)$ & $503(17)$ & $95(62)$ & $313(4)$ & $365(-15)$ & $94(-10)$ & $224(9)$ & $350(-8)$ \\
OTH & $4(3)$ & $3(2)$ & $4(4)$ & $2(-0.7)$ & $4(4)$ & $138(4)$ & $14(4)$ & $4(3)$ & $4(4)$ & $2(3)$ \\
\hline Total & $388(14)$ & $338(20)$ & $135(10)$ & $1978(19)$ & $721(46)$ & $1844(21)$ & $963(-8)$ & $327(-1)$ & $1078(23)$ & $1251(13)$ \\
\hline
\end{tabular}


Annex 5.B. Changes in Vietnam's Exports by Source

\begin{tabular}{|c|cccccccccc|}
\hline \multicolumn{7}{|c}{ IDN } & MYS & PHL & \multicolumn{7}{c|}{ SGP } & THA & NIES & EU15 & USA & CHI & JPN \\
\hline AGR & $99(98)$ & $52(-0.3)$ & $10(160)$ & $189(-2)$ & $22(3)$ & $165(-2)$ & $298(-3)$ & $153(-3)$ & $40(-3)$ & $74(-3)$ \\
PAG & $87(0.4)$ & $95(0.4)$ & $33(1)$ & $34(0.3)$ & $53(334)$ & $44(0.2)$ & $49(0.2)$ & $23(0.2)$ & $162(0.2)$ & $371(0.2)$ \\
BTP & 0 & 0 & 0 & $0.3(4)$ & 0 & $2(3)$ & $0.1(0)$ & $0.4(5)$ & $0.6(2)$ & $1(3)$ \\
COG & $19(0.2)$ & $2(0)$ & $3(16)$ & $194(0.2)$ & $12(61)$ & $14(0.1)$ & $56(0.1)$ & $2(0)$ & $121(0.1)$ & $724(0.1)$ \\
PCP & 0 & 0 & 0 & 0 & 0 & 0 & $0.3(4)$ & 0 & $0.8(3)$ & 0 \\
TEX & -34 & $2(37)$ & $2(78)$ & $2(4)$ & $0.4(192)$ & $51(4)$ & $22(4)$ & $0.1(0)$ & $1(4)$ & $67(4)$ \\
CLO & 0 & $2(86)$ & 0 & $13(14)$ & $0.2(1000)$ & $31(14)$ & $453(14)$ & $22(14)$ & $0.5(14)$ & $443(14)$ \\
LMF & $0.1(29)$ & $13(71)$ & $1(244)$ & $12(5)$ & $29(344)$ & $40(5)$ & $721(5)$ & $7(5)$ & $15(5)$ & $158(5)$ \\
BMF & $1(12)$ & $17(3)$ & $0.8(153)$ & $10(2)$ & $3(39)$ & $9(2)$ & $45(2)$ & $2(2)$ & $3(2)$ & $8(2)$ \\
CRP & $3(43)$ & $2(29)$ & $2(68)$ & $14(2)$ & $1(119)$ & $4(2)$ & $16(2)$ & $2(2)$ & $7(2)$ & $5(2)$ \\
TRP & 0 & $0.3(88)$ & $1(119)$ & $2(10)$ & $1(116)$ & $8(10)$ & $6(10)$ & 0 & $3(10)$ & $0.2(12)$ \\
MCE & $2(5)$ & $5(25)$ & $2(5)$ & $29(5)$ & $1(42)$ & $22(5)$ & $11(5)$ & 0 & $1(5)$ & $8(5)$ \\
OTH & $38(-0.6)$ & $5(-0.6)$ & $19(-0.6)$ & $7(-0.5)$ & $22(-0.5)$ & $114(-0.7)$ & $381(-0.7)$ & $129(-0.7)$ & $19(-0.7)$ & $386(-0.6)$ \\
\hline Total & $252(25)$ & $196(5)$ & $75(17)$ & $507(0)$ & $145(97)$ & $504(1)$ & $2057(4)$ & $341(-0.6)$ & $373(0.2)$ & $2244(3)$ \\
\hline
\end{tabular}

\begin{tabular}{|c|cccccccccc|}
\hline \multicolumn{10}{|c|}{ SCENARIO 2 (AFTA 2) } \\
\hline AGR & $96(91)$ & $51(-3)$ & $9(150)$ & $183(-6)$ & $21(-0.5)$ & $160(-5)$ & $287(-6)$ & $148(-6)$ & $39(-6)$ & $71(-6)$ \\
PAG & $85(-2)$ & $191(103)$ & $164(397)$ & $33(-2)$ & $52(323)$ & $43(-2)$ & $47(-2)$ & $23(-2)$ & $158(-2)$ & $362(-2)$ \\
BTP & 0 & 0 & 0 & $0.3(0)$ & 0 & $2(0)$ & $0.1(0)$ & $0.4(0)$ & $0.6(0)$ & $1(0)$ \\
COG & $19(0)$ & $1(0)$ & $3(15)$ & $193(-0.1)$ & $12(61)$ & $14(-0.1)$ & $56(-0.2)$ & $2(-0.6)$ & $120(-0.2)$ & $722(-0.2)$ \\
PCP & 0 & 0 & 0 & 0 & 0 & 0 & $0.3(4)$ & 0 & $0.8(3)$ & 0 \\
TEX & $1(32)$ & $2(35)$ & $2(76)$ & $2(3)$ & $0.4(192)$ & $50(2)$ & $21(2)$ & $0.1(0)$ & $1(3)$ & $66(2)$ \\
CLO & 0 & $2(81)$ & 0 & $13(11)$ & $0.2(950)$ & $30(11)$ & $440(11)$ & $21(11)$ & $0.5(11)$ & $431(10)$ \\
LMF & $0.1(29)$ & $13(67)$ & $1(235)$ & $12(3)$ & $28(333)$ & $39(2)$ & $703(2)$ & $7(3)$ & $15(2)$ & $154(3)$ \\
BMF & $1(9)$ & $17(0.5)$ & $0.8(147)$ & $10(-0.4)$ & $3(37)$ & $9(-0.7)$ & $44(-0.6)$ & $2(-0.6)$ & $3(-0.7)$ & $7(-0.5)$ \\
CRP & $3(42)$ & $2(27)$ & $2(67)$ & $14(1)$ & $1(118)$ & $4(1)$ & $16(1)$ & $2(1)$ & $7(1)$ & $4(1)$ \\
TRP & 0 & $0.3(82)$ & $1(111)$ & $2(6)$ & $1(107)$ & $8(6)$ & $6(6)$ & 0 & $3(6)$ & $0.3(8)$ \\
MCE & $2(3)$ & $4(23)$ & $2(3)$ & $29(3)$ & $1(39)$ & $22(3)$ & $11(2)$ & $0.1(0)$ & $0.6(3)$ & $8(3)$ \\
OTH & $37(-2)$ & $5(-2)$ & $19(-3)$ & $8(-2)$ & $21(-2)$ & $111(-2)$ & $374(-2)$ & $127(-2)$ & $18(-3)$ & $379(-2)$ \\
\hline Total & $246(22)$ & $290(56)$ & $205(218)$ & $498(-2)$ & $142(92)$ & $492(-1)$ & $2005(2)$ & $331(-3)$ & $367(-2)$ & $2206(1)$ \\
\hline
\end{tabular}

\begin{tabular}{|c|cccccccccc|}
\hline \multicolumn{10}{|c|}{ SCENARIO 3 (AFTA 3) } \\
\hline AGR & $98(94)$ & $52(-1)$ & $9(154)$ & $186(-4)$ & $22(2)$ & $162(-4)$ & $292(-5)$ & $150(-5)$ & $40(-5)$ & $72(-5)$ \\
PAG & $87(0.5)$ & $196(108)$ & $168(408)$ & $34(2)$ & $53(334)$ & $44(0.3)$ & $49(0.3)$ & $23(0.3)$ & $162(0.2)$ & $372(0.3)$ \\
BTP & 0 & 0 & 0 & $0.3(4)$ & 0 & $2(4)$ & $0.1(0)$ & $0.4(5)$ & $0.6(4)$ & $1(4)$ \\
COG & $19(2)$ & $2(2)$ & $4(18)$ & $198(2)$ & $12(64)$ & $15(2)$ & $57(2)$ & $2(2)$ & $123(2)$ & $738(2)$ \\
PCP & 0 & 0 & 0 & 0 & 0 & 0 & $0.3(8)$ & 0 & $0.8(5)$ & 0 \\
TEX & $1(33)$ & $2(37)$ & $2(79)$ & $2(4)$ & $0.4(192)$ & $51(4)$ & $22(4)$ & $0.1(0)$ & $1(4)$ & $67(4)$ \\
CLO & 0 & $2(83)$ & 0 & $13(12)$ & $0.2(1000)$ & $30(11)$ & $444(12)$ & $21(12)$ & $0.5(12)$ & $434(11)$ \\
LMF & $0.1(43)$ & $13(70)$ & $1(247)$ & $12(5)$ & $29(342)$ & $39(4)$ & $716(4)$ & $7(5)$ & $15(4)$ & $157(4)$ \\
BMF & $1(14)$ & $17(5)$ & $0.8(156)$ & $10(4)$ & $3(42)$ & $9(3)$ & $46(3)$ & $2(3)$ & $3(3)$ & $8(3)$ \\
CRP & $3(44)$ & $2(29)$ & $2(70)$ & $14(3)$ & $1(121)$ & $4(3)$ & $16(3)$ & $2(3)$ & $7(3)$ & $5(3)$ \\
TRP & $0.1(25)$ & $0.4(106)$ & $2(142)$ & $2(22)$ & $1(141)$ & $9(22)$ & $7(22)$ & 0 & $4(22)$ & $0.3(24)$ \\
MCE & $2(9)$ & $5(28)$ & $2(7)$ & $30(7)$ & $1(78)$ & $23(7)$ & $11(7)$ & $0.1(17)$ & $0.6(7)$ & $9(7)$ \\
OTH & $39(2)$ & $5(1)$ & $19(1)$ & $8(2)$ & $22(2)$ & $116(1)$ & $389(1)$ & $132(1)$ & $19(1)$ & $394(1)$ \\
\hline Total & $251(25)$ & $297(59)$ & $210(226)$ & $509(0.4)$ & $146(98)$ & $504(1)$ & $2048(4)$ & $340(-0.8)$ & $376(0.8)$ & $2256(3)$ \\
\hline
\end{tabular}

\begin{tabular}{|c|cccccccccc|}
\hline \multicolumn{10}{|c|}{ SCENARIO 4(UNILATERAL) } \\
\hline AGR & $93(85)$ & $49(-6)$ & $9(142)$ & $177(-9)$ & $21(-3)$ & $155(-8)$ & $277(-10)$ & $142(-10)$ & $37(-9)$ & $69(-10)$ \\
PAG & $83(-4)$ & $187(99)$ & $160(386)$ & $32(-4)$ & $50(312)$ & $42(-5)$ & $46(-5)$ & $22(-5)$ & $154(-4)$ & $353(-5)$ \\
BTP & 0 & 0 & 0 & $0.3(0)$ & 0 & $2(0)$ & $0.1(0)$ & $0.4(0)$ & $0.6(-2)$ & $1(0)$ \\
COG & $19(2)$ & $2(1)$ & $3(17)$ & $197(2)$ & $12(64)$ & $15(1)$ & $57(2)$ & $2(2)$ & $123(2)$ & $735(2)$ \\
PCP & 0 & 0 & 0 & 0 & 0 & 0 & $0.3(8)$ & 0 & $0.8(6)$ & 0 \\
TEX & $2(56)$ & $3(60)$ & $3(109)$ & $2(22)$ & $0.4(242)$ & $60(22)$ & $25(22)$ & $0.1(17)$ & $1(22)$ & $78(22)$ \\
CLO & 0 & $4(203)$ & 0 & $22(85)$ & $0.4(1650)$ & $50(86)$ & $738(85)$ & $36(86)$ & $0.8(86)$ & $716(83)$ \\
LMF & $0.1(71)$ & $15(96)$ & $1(297)$ & $14(20)$ & $33(407)$ & $45(20)$ & $825(20)$ & $8(20)$ & $17(20)$ & $180(20)$ \\
BMF & $1(8)$ & $16(-0.2)$ & $1(147)$ & $10(-1)$ & $3(36)$ & $9(-1)$ & $44(-1)$ & $2(-2)$ & $3(-1)$ & $7(-1)$ \\
CRP & $3(44)$ & $2(29)$ & $2(69)$ & $14(3)$ & $1(121)$ & $4(3)$ & $16(3)$ & $2(3)$ & $7(3)$ & $5(3)$ \\
TRP & $0.1(25)$ & $0.4(124)$ & $2(159)$ & $3(31)$ & $1(157)$ & $10(31)$ & $7(31)$ & 0 & $4(31)$ & $0.3(32)$ \\
MCE & $2(10)$ & $5(29)$ & $2(9)$ & $30(8)$ & $1(80)$ & $23(8)$ & $11(8)$ & $0.1(17)$ & $0.7(8)$ & $9(8)$ \\
OTH & $36(-6)$ & $5(-6)$ & $18(-6)$ & $7(-6)$ & $21(-6)$ & $108(-6)$ & $361(-6)$ & $122(-6)$ & $18(-6)$ & $366(-6)$ \\
\hline Total & $240(19)$ & $288(55)$ & $201(213)$ & $508(0.1)$ & $145(96)$ & $522(5)$ & $2408(22)$ & $337(-2)$ & $368(-1)$ & $2519(15)$ \\
\hline
\end{tabular}





\section{Policy Research Working Paper Series}

Title

WPS2201 Financial Development and Industrial Capital Accumulation

WPS2202 Specialization without Regret: Transfer Rights, Agricultural Productivity, and Investment in an Industrializing Economy

WPS2203 Market versus Administrative Reallocation of Agricultural Land in a Period of Rapid Industrialization

WPS2204 Corruption under Moral Hazard

WPS2205 Foreign-Owned Capital and Endogenous Tariffs

WPS2206 Household Childcare Choices and Women's Work Behavior in Russia

WPS2207 Jamaica's Food Stamp Program: Impacts on Poverty and Welfare

WPS2208 Ethnic Partition as a Solution to Ethnic War: An Empirical Critique of the Theoretical Literature

WPS2209 Does Corruption Relieve Foreign Investors of the Burden of Taxes and Capital Controls?

WPS2210 The Sliperry Slope: Explaining the Increase in Extreme Poverty in Urban Brazil, 1976--96

WPS2211 Competition Policy, Developing Countries, and the World Trade Organization

WPS2212 Is African Manufacturing SkillConstrained?

WPS2213 Fiscal Solvency and Sustainability in Economic Management
Author

Biagio Bossone

Michael R. Carter

Yang Yao

Michael R. Carter

Yang Yao

Gunnar S. Eskeland

Henrik Thiele

Marcelo Olarreaga

Michael M. Lokshin

Kene Ezemenari

Kalanidhi Subbarao

Nicholas Sambanis

Shang-Jin Wei

Francisco H. G. Ferreira

Ricardo Paes de Barros

Bernard Hoekman

Peter Holmes

Howard Pack

Christina Paxson

Hinh T. Dinh

\section{Date}

October 1999

October 1999

October 1999

October 1999

October 1999

October 1999

October 1999

October 1999

October 1999

October 1999

October 1999

October 1999

October 1999
M. Fernandez 33766

G. llogon 33732

L. Tabada 36896

\section{Contact} for paper

E. Mekhova 85984

M. Fernandez 33766

H. Sladovich 37698

L. Tabada 36896

P. Sader 33902

G. Peralta 37405

H. Sladovich 37698

H. Sladovich 37698

H. Sladovich 37698

M. Rani 32057 


\section{Policy Research Working Paper Series}

Title

WPS2214 Trade Policy and Market Access Issues for Developing Countries: Implications for the Millennium Round

WPS2215 Implementation of Uruguay Round Commitments: The Development Challenge

WPS2216 Corruption and Trade Tariffs, or a Case for Uniform Tariffs

WPS2217 Border, Border, Wide and Far, How We Wonder What You Are

WPS2218 Who Avoids and Who Escapes Poverty during the Transition: Evidence from Polish Panel Data, 1993-96

WPS2219 The Effect of the United States' Granting Most Favored Nation Status to Vietnam
Author

Constantine Michalopoulos October 1999

J. Michael Finger

Philip Schuler

Roberta Gatti

David C. Parsley

Shang-Jin Wei

Wlodzimierz Okrasa

Emiko Fukase

Will Martin
Date

October 1999

Contact for paper

L. Tabada 36896

October 1999

R. Gatti 38735

November 1999

H. Sladovich 37698

November 1999

S. Fallon 38009

November 1999
L. Tabada 36896

1110 